\title{
Fungal ethnoecology: observed habitat preferences and the perception of changes in fungal abundance by mushroom collectors in Poland
}

\author{
Marcin Andrzej Kotowski $i^{1,23^{*}}$, Zsolt Molnár ${ }^{1}$ and Łukasz Łuczaj $j^{3}$
}

\begin{abstract}
Background: Scientists frequently raise the topic of data deficiency related to the abundance and distribution of macrofungi in the context of climate change. Our study is the first detailed documentation on locals' perception of fungal ecology which covers a large mycophilous region of Europe (Mazovia, Poland).

Methods: A total of 695 semi-structured interviews were carried out among local informants in 38 localities proportionally distributed throughout the study area (one locality approximately every $30 \mathrm{~km}$ ). Interview questions concerned fungi species collected, their perceived habitats, and whether any changes had been noted in their abundance. As many as 556 respondents provided information concerning fungal ecology. In these descriptions, 35 taxa were mentioned by at least 5 respondents.

Results: The data collected during interviews allowed us to create collective folk descriptions of habitat preferences and a list of 98 different macro-, meso-, and microhabitats of macrofungi described by the respondents. This list of recurring habitats assigned to particular macrofungal taxa coincides with, and sometimes exceeds, data available in scientific publications. Some habitat preferences observed by the informants have not yet been researched or tested by science.

Out of 695 respondents, 366 (53\%) noticed a steady decrease in local macrofungi abundance, and only one person claimed to have observed a steady increase. Imleria badia was the only species with increased abundance, as noted by fifteen independent respondents. The main listed reason for abundance decrease was drought $(f=186)$.

Conclusions: Collected information on the ecology of fungi shows that local knowledge does not generally diverge from scientific knowledge. The acquired information related to macrofungal abundance and ecology may also be used as a tool for the formulation of new scientific questions and theories. The analysis of local fungi observations might contribute to broadening knowledge about local changes in fungi and enable new estimations related to large-scale analysis of macrofungal abundance.
\end{abstract}

Keywords: Ethnomycology, Ethnoecology, Folk habitats, Perception of change, Macromycetes, Fungi, Abundance, Habitat preference, Hypotheses, Mazovia

\footnotetext{
* Correspondence: marcin.andrzej.kotowski@gmail.com

'Institute of Ecology and Botany, Centre for Ecological Research, Vácrátót $\mathrm{H}-2163$, Hungary

${ }^{2}$ Botanical Garden Center for Biological Diversity Conservation in Powsin, Polish Academy of Sciences, Warsaw, Poland

Full list of author information is available at the end of the article
}

C C The Author(s). 2021 Open Access This article is licensed under a Creative Commons Attribution 4.0 International License, which permits use, sharing, adaptation, distribution and reproduction in any medium or format, as long as you give appropriate credit to the original author(s) and the source, provide a link to the Creative Commons licence, and indicate if changes were made. The images or other third party material in this article are included in the article's Creative Commons licence, unless indicated otherwise in a credit line to the material. If material is not included in the article's Creative Commons licence and your intended use is not permitted by statutory regulation or exceeds the permitted use, you will need to obtain permission directly from the copyright holder. To view a copy of this licence, visit http://creativecommons.org/licenses/by/4.0/. The Creative Commons Public Domain Dedication waiver (http://creativecommons.org/publicdomain/zero/1.0/) applies to the data made available in this article, unless otherwise stated in a credit line to the data. 


\section{Introduction}

Since the mid-1950s, scientists have explored patterns of shared environmental knowledge that emerged from indigenous practices based on local human-nature relationships [1, 2]. This new research area came to form the broad cross-discipline of ethnoscience-a field of science based on collaboration between social and natural sciences [3]. Researchers who study local ecological issues have noticed that local traditional communities have developed an extensive body of traditional ecological knowledge (TEK) about plants, animals, fungi, ecosystems, landscapes, and the processes and changes they undergo [4]. This knowledge emerged from longterm observations, experiments, and direct personal interactions with surrounding living nature [5]. A rise in scientific interest in this body of knowledge led to the development of ethnoecology-a new sub-field of ethnoscience. Ethnoecology is the scientific study of how different groups of people living in different locations understand the ecosystems around them and what relationships they form with their surrounding environments [6]. Ethnomycology broadly considers human engagement with the kingdom of fungi, bringing together the interests of the humanities, fine arts, and social and natural sciences [7]. Our present research was conducted following a traditional view on fungal ecology.

Traditional ecological knowledge is not only 'used' by the local communities that develop and possess this knowledge, but it also provides its users with a deep understanding of the status and changes to the local environment. This knowledge can often complement scientific understanding [8], help environmental monitoring [9], and support the planning and execution of adaptive conservation management [10]. Additionally, local and traditional ecological knowledge can help to develop new scientific questions and testable hypotheses [11, 12]

Traditional ecological knowledge can be related to habitat and ecosystem types, including habitat classification and landscape partitioning [13, 14]. Although this domain still requires research, recent studies analysing folk habitat types have proven the complexity and multidimensional characteristics of folk habitat descriptions and landscape partitionings. The studies conducted by Babai and Molnár [15] among Csángó people living in Gyimes (Carpathians, Romania) have also underlined the importance of the scale dimension, which plays a major role in folk habitat classifications. The significance of topographical and topological aspects of scale in folk habitat classifications has also been confirmed by Gantuya et al. [16] among Mongolian herders. In general, folk habitat types can be grouped into macro-, meso-, and micro-scale habitats. Macrohabitats usually occupy large areas and comprise many habitat types, forming a mosaic. Mesohabitats are usually smaller in extension, homogenous, and often dominated by a single type of vegetation. Microhabitats are embedded in mesohabitats and provide special niches for particular species [14].

Because environmental changes are caused not only by natural but also by societal processes, by interacting and shaping their environment, local communities have developed their own perception of these changes [17]. Recently, local observations of environmental change are becoming recognized by science [18]. According to Nakashima et al. [19], people who interact with nature on a daily basis display knowledge that can be essential in introducing measurements to adapt and fight climate change. In her work, Gantuya et al. [16], besides noticing the important role of seasonal changes and pasture dynamics in determining the most suitable grazing area, emphasized the importance of long-term ecological stability for local herders. Ujházy et al. [20] compared farmers' and conservationists' perception of landscape changes. The results showed that the two groups shared similar views on perceived landscape changes, but they evaluated these changes differently. Farmers mostly focused on the impact on habitat usefulness, while conservationists had a primarily eco-centric approach. The common message of studies focusing on folk knowledge in relation to environmental change is the need for a deeper understanding of local perceptions [18, 21]. Studying local knowledge could broaden our understanding of the trends in ongoing ecological changes [22]. Having completed quantitative analysis of a large number of interviews, it is also possible to provide important information on the heterogeneity of social landscape perception [20].

The few studies that document local and traditional knowledge of fungal habitats and population changes (incl. abundance) usually focus on individual species [23, 24]. Lampman [25], however, undertakes a complete documentation of fungi-related knowledge shared by the Tzeltal Maya of the Chiapas highlands. In his work, Lampman focuses on knowledge concerning wild edible fungi ecology. However, the characteristics he describes often only provide a general overview of locally used macrofungi, without any detailed data on particular species. Lampman recorded information on the relationship of particular taxa to characteristics such as substrate preference, but without providing quantitative data (e.g. number of informants).

In our present study on fungal ethnoecology, we have the following objectives:

- To document the habitat types used by local Polish mushroom collectors to describe the habitat preferences of various fungal taxa; 
- To document the habitat preference of each mushroom species by appealing to the observations of a large number of mushroom collectors;

- To analyse local perception of macrofungal population trends (abundance) using local observations as a specific form of fungi monitoring;

- Finally, to generate a hypothesis for further research on fungi based on the above observations.

\section{Methods}

\section{Research area}

Mazovia is a historical region that lies in the CentralEastern part of Poland. It is one of the ten major Polish historical regions within the country's present-day borders. Mazovia was an independent principality throughout a major part of Polish mediaeval history [26]. In the case of the present study, its borders were determined by a map created for the 'Historical Atlas of Poland in the $2^{\text {nd }}$ Half of the $16^{\text {th }}$ Century' by Pałucki [27] (Fig. 1).

The region lies mainly within the current borders of the Mazovian Voivodeship and extends to part of the Łódź Voivodeship in the south-west and to Podlasie Voivodeship in the north-east. It covers about $33,900 \mathrm{~km}^{2}$, spreading over the Mazovian Lowland in the valleys of the Vistula, Bug, and Narew rivers. It is currently inhabited by around 5.03 million people [28]. Mazovia is characterized by a cold temperate climate with high annual temperature amplitudes and a transitional character between oceanic and continental [29]. The average temperature (VI-VIII) is around $18{ }^{\circ} \mathrm{C}$ in the summer and $1{ }^{\circ} \mathrm{C}$ during winter (XII-II). Average annual rainfall ranges from 550 to $600 \mathrm{~mm}$ [30]. Forest vegetation covers $23.3 \%$ of the research area [31], the majority of which are coniferous forests (64\%) mainly composed of Pinus sylvestris L.. The other species that are the most abundant in mixed and deciduous forests are Quercus robur L. and Betula pendula Roth.

Folk cultural characteristics shared by people living in this historical region are currently difficult to find. However, the region is still inhabited by a few ethnographic groups. Usually, they can be distinguished by their local traditions and cultures. These groups are the Podlasianie, Mazurzy, Łowiczanie, and Kurpie [32]. The capital city of Warsaw is situated in the centre of Mazovia. Despite the broad urban sprawl surrounding Warsaw, there are even forests used for recreational mushroom picking in the city's agglomeration.

The research was conducted in 38 villages or small market towns, which were dispersed in a $30-\mathrm{km}$ grid throughout the whole Mazovian region (Fig. 1). These were Burakowskie, Całowanie, Chyżyny, Cieciory, Dąbrowa, Faustynowo, Flesze, Gostkowo, Kluki, Klusek, Kocierzew, Konopki (Grajewo County), Konopki (Łomża
County), Korytów, Kozietuły, Kręgi, Leksyn, Łątczyn, Łękawica, Mamino, Mchowo, Mistrzewice, Nowy Gołymin, Piaski, Przedświt, Psucin, Pszczonów, Radzymin, Regnów, Sojczyn, Stare Babice, Szczaki, Szydłowo, Świerże, Węgrzynowice, Wyrzyki, Zdunek, and Żurawka (currently the district of Sulejówek).

This network of settlements forms part of the larger grid of the Ethnographic Atlas of Poland, which was also used to collect data on mushroom picking between 1964 and 1969. At that time, chosen localities were described as 'large moderately backward' settlements.

\section{Field research}

The field research took place between 2014 and 2018, from April to November-the months of abundance of traditionally collected wild edible fungi in Poland. Data collection was spread evenly across the research period, while the volume of collected data depended mostly on weather conditions and population density. Data were collected through individual semi-structured interviews conducted among local informants, which constitutes the classic method in ethnobiology [33]. Aside from data concerning local knowledge on collected species, folk taxonomy and cultural significance presented in previous work [34], we have also documented knowledge about collected species ecology and their changes in abundance observed during the years of active fungi collection (usually since childhood to the day of interview). Information about macrofungi gathered or recognized as edible was collected by using the freelisting method. All freelists were made orally and written down. Questions relating to knowledge about species habitat and changes to abundance were asked in relation to each listed species. The information was acquired through informants' answers to general questions: 'Where would you look for this mushroom species?', 'Did you notice any changes in the abundance of this species?', and 'What do you think is the main cause of mushroom abundance changes?' All of 695 respondents were asked questions concerning fungal habitat and abundance changes. Not everyone was able to answer them. In case of habitat descriptions, lack of answer was classified as 'unknown'; therefore, it was not used in habitat description and analysis (Table 1). In case of abundance changes, lack of answer was classified as 'unnoticed' and is present in data analysis (Fig. 4).

At least one landscape walk or joined collection trip was conducted in each village. The majority of voucher specimens for further identification were collected fresh during field interviews, and some were acquired in dried form from respondents. A total of 695 individual interviews have been conducted where respondents provided information on folk taxonomy of collected fungi species [34]. Among them, 556 respondents provided information on fungal ecology related to 92 taxa. Women 


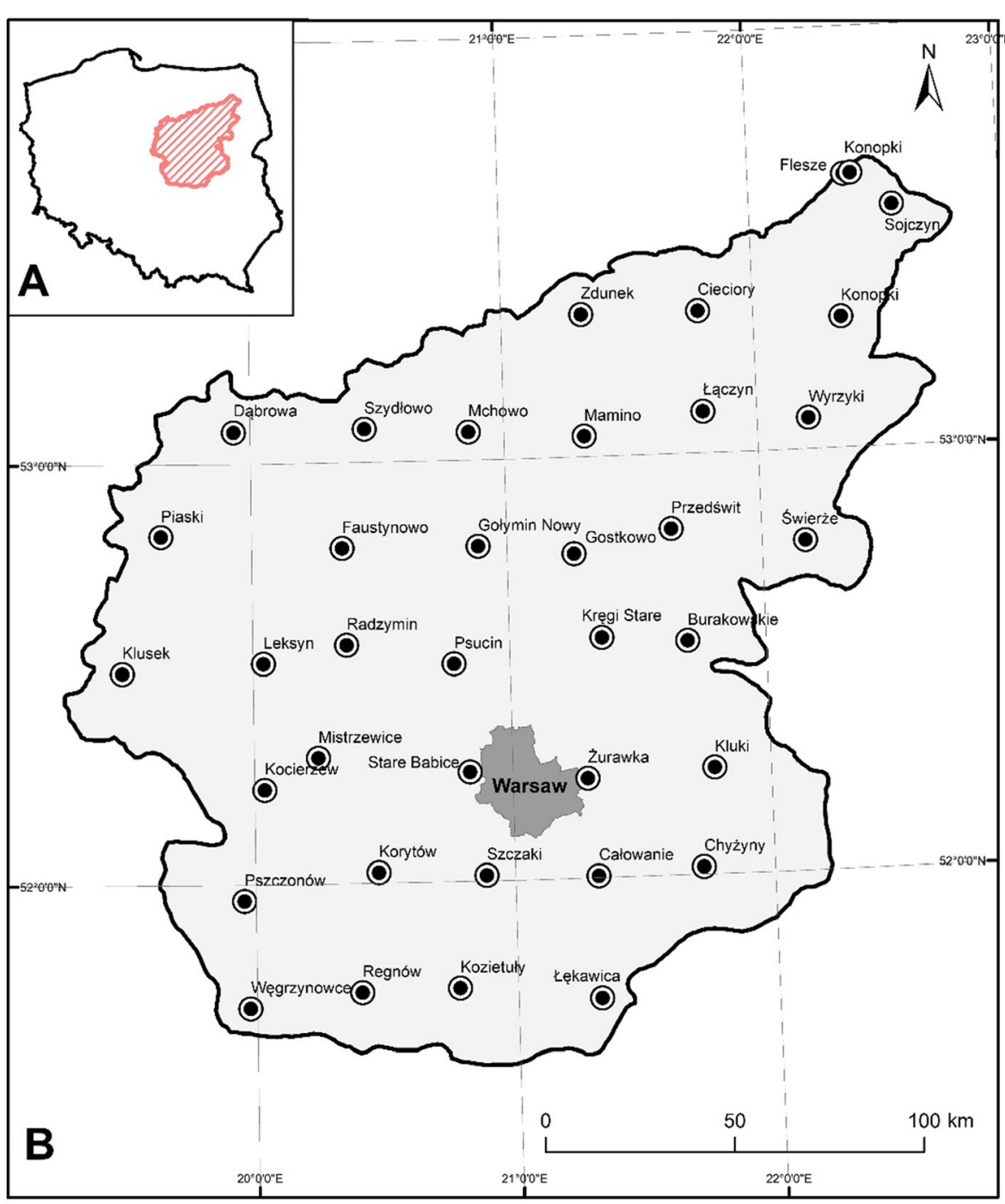

Research localities

A - Research area within the borders of Poland

B - Historical borders of the Mazovia region

Fig. 1 Research area

accounted for $52 \%$ (362) and men for $48 \%$ (333). The age of informants ranged from 17 to 95 . The mean age was $63(\mathrm{SD}=13.7)$ and the median 64 . Informants were selected during village walks or using the 'snowball' sampling technique [35]. The selection of informants was haphazard-based on their willingness to participate in the interview-and therefore socio-demographic characteristics were varied. However, like in most ethnobiological studies, we aimed at talking to middle-aged and older people.

\section{Data analysis}

The majority of fungal fruiting bodies were identified with the support of mushroom pictures or identification guides [36]. Some of the interviews were conducted simultaneously with mushroom collection. This method enabled us to recognize taxa on the spot and to collect voucher specimens, which were additionally identified by DNA barcoding [34].

All folk habitat terms mentioned by the respondents in the interviews were extracted and grouped. Synonymous folk habitat names were grouped according to dimensions such as dominant symbiotic species, succession, land use, vegetation structure, forest vegetation physiognomy, geomorphology, soils, hydrology, human, and animal disturbances $[15,16]$.

After analysing 556 interviews and 3999 reports concerning particular fungal taxa, we also selected 35 taxa 
Table 1 Habitat types used to describe the habitat preference of various mushroom species listed by the respondents $(n=556)$.

\begin{tabular}{|c|c|c|}
\hline Habitat & Frequency & Habitat \\
\hline Pine Pinus sylvestris L. (occurrence correlated with pine presence) & 1178 & Blackberries (Rubus L. spp.) \\
\hline Birch (Betula L. spp.) & 746 & Boar rooting (grounds disturbed by boar activity) \\
\hline Mixed forests (coniferous and deciduous) & 622 & Orchards \\
\hline Sandy soils & 383 & Water's edge \\
\hline Small/young trees & 381 & Firebreaks \\
\hline Oak (Quercus L. spp). & 345 & Hazel (Corylus avellana L.) \\
\hline Coniferous forests & 334 & On trees \\
\hline Meadows & 221 & Hills/scarps \\
\hline Moss (presence in the groundcover) & 217 & Potato fields \\
\hline Terrain elevations/hillocks & 206 & Snow (under the snow-cover) \\
\hline forest edge & 170 & Bogs \\
\hline Deciduous forests & 146 & Near feeding rack \\
\hline Various habitats (occurring in many unrelated habitats) & 138 & Stubble \\
\hline Grasses & 135 & Thin forests \\
\hline Old/tall forests & 129 & White moss (Leucobryum glaucum (Hedw.) Ångstr.) \\
\hline Roadsides & 104 & Balks (i.e. strips between fields) \\
\hline Tree stumps & 103 & Lichens \\
\hline Common aspen & 83 & Parks \\
\hline Humid soils & 78 & Short grass \\
\hline Fields & 76 & Beech (Fagus sylvatica L.) \\
\hline Trenches/depressions & 62 & Bird cherry (Prunus padus L.) \\
\hline Litter with conifer needles & 59 & Black poplar (Populus nigra L.) \\
\hline Thickets & 52 & Fallen pine bark/mulching bark \\
\hline Cows/horses (presence - mainly pastures) & 49 & Frangula alnus Mill. \\
\hline Spruce (Picea abies (L.) H.Karst.) & 48 & Robinia pseudoacacia L. \\
\hline Forest clearings & 43 & Bog blueberry (Vaccinium uliginosum L.) \\
\hline Alder (Alnus Mill. spp.) & 41 & Secondary forest \\
\hline Heather (Calluna vulgaris (L.) Hull) & 39 & Near tree trunks \\
\hline Under fallen branches & 39 & Poplars (Populus L. spp.) \\
\hline Clear/light forest & 35 & Rich undergrowth \\
\hline Clearcutting areas & 33 & Without undergrowth \\
\hline Dry soils & 33 & Ash tree (Fraxinus excelsior L.) \\
\hline Blueberries (Vaccinium myrtillus L.) & 29 & Burned areas \\
\hline Open areas & 29 & Compost \\
\hline Yards & 28 & Dense forest \\
\hline High sun exposure & 25 & Elder trees (Sambucus nigra L.) \\
\hline Fallows/wastelands & 23 & Elm (Ulmus L. spp.) \\
\hline Among litter & 21 & Ferns \\
\hline Hornbeam (Carpinus betulus L.) & 19 & Fertile soil \\
\hline Juniper (Juniperus communis L.) & 16 & Fir (Abies alba Mill.) \\
\hline Larch (Larix decidua Mill.) & 15 & Foxholes \\
\hline Dead wood & 14 & Garbage dumps \\
\hline Self-sown forest & 14 & Green moss \\
\hline Forest plantations & 12 & Hardwood trees \\
\hline
\end{tabular}

8


Table 1 Habitat types used to describe the habitat preference of various mushroom species listed by the respondents $(n=556)$. (Continued)

\begin{tabular}{|c|c|c|c|}
\hline Habitat & Frequency & Habitat & Frequency \\
\hline Enshadowed areas & 11 & Near the bunkers (after the war) & 1 \\
\hline Medium aged forests & 10 & Railroad trackway & 1 \\
\hline Thick litter layer & 10 & Ridges & 1 \\
\hline Behind the barn (buildings near open areas) & 9 & Thin litter layer & 1 \\
\hline Animal manure & 8 & Near log piles & 1 \\
\hline
\end{tabular}

with 5 or more individual ecological descriptions (Fig. 2). In order to remove singular folk reports and focus on the most frequently mentioned habitats, we only selected habitats that were listed by more than $5 \%$ of respondents in relation to particular taxa and were listed more than once. Habitats mentioned by a fewer number of respondents were grouped as 'other'. In order to present the acquired data, we used Sankey diagram created with the use of Tableau software version 2020.4.

PCA analysis was conducted on the basis of the matrix of the most frequently mentioned habitats in relation to different fungal taxa, which were selected in analysis presented in Fig. 2. The main purpose of the principal component analysis is to compute the principal components (in this case elements describing fungal habitats) and use them to determine certain groups of species related to specific multidimentional habitat description. This allows for a reduction in the dimensionality of data while preserving its variation. The first principal components can define which direction maximizes the variation of projected points, therefore enabling the division of certain fungal species into groups with similar habitat preferences. Data processing included normalization using the min-max scaling method and singular value decomposition (SVD). PCA analysis was performed in R programming language using the FactoMineR package in Rstudio software [37] (Fig. 3).

In order to compare folk ecology descriptions with scientific knowledge, we used the 'Checklist of Polish Larger Basidiomycetes' [38] as a reference point for the Basidiomycota species and 'Grzyby i ich oznaczanie' [39] for Ascomycota. This was supplemented with data from other scientific publications.

We recorded the number of respondents who noticed a change in general macrofungal abundance during the period of mushroom collection. In some cases, we collected reports on observed abundance changes of particular fungi. The collected data was used to create Macrofungi abundance decrease maps that recorded the main causes of these changes (Fig. 4). These maps were created on the basis of data collected in particular localities. Interpolations were made with the geometric interval method. Answers were classified as 'anthropopressure' when respondents mentioned human agents affecting the habitat in general without directly specifying official forest management. All maps were created using ArcMap 10.4.1.

\section{Results}

Habitats listed by locals to describe habitat preference of mushroom species

We found 98 habitat types mushroom collectors used to describe habitats of collected fungi (Table 1). Most habitats (65) may be regarded as mesic habitats (e.g. different forest types, such as coniferous forest, deciduous forest, mixed forest, pine forest, forest edges, openings), 28 as microhabitats (e.g. terrain elevations or hillocks, roadsides, tree stumps or fallen pine bark), and 4 as macro habitats (e.g. areas with or without forest vegetation).

Folk habitats referred to different characteristics of these habitats. The main dimensions were dominant species (e.g. Pinus sylvestris L., Populus tremula L.), vegetation succession (clearcut, forest plantation, forest age, grass presence, deadwood presence, forest density, grass size), land-use type (forests, pastures, meadows, fields, fallows, wastelands, orchards, yards, stubbles, parks), vegetation structure (coniferous forest, deciduous forest, mixed forest, forest edge, forest cover and understory structure, hardwood forest), forest vegetation physiognomy (open forest, forest clearings, little exposure to sun, burned areas), geomorphology (terrain elevations, hills, hillocks, scarps, trenches, depressions, slopes, water edge), soils (sandy, fertile), hydrology (humid, dry, bogs), human and animal disturbances (roadsides, presence of tree stumps, presence of human-made structures, firebreaks, balks, boar rooting, manure presence, foxholes), and history of land use (forests on previously cultivated grounds).

\section{Observed habitat preference of mushroom species}

Field data concerning local knowledge about collected fungi species habitat preferences acquired during the field research was compiled into collective habitat descriptions for 35 different fungal taxa, enabling the creation of quantitative graphs depicting the most important habitats determining particular fungi species occurrence (Fig. 2, Table 3). 


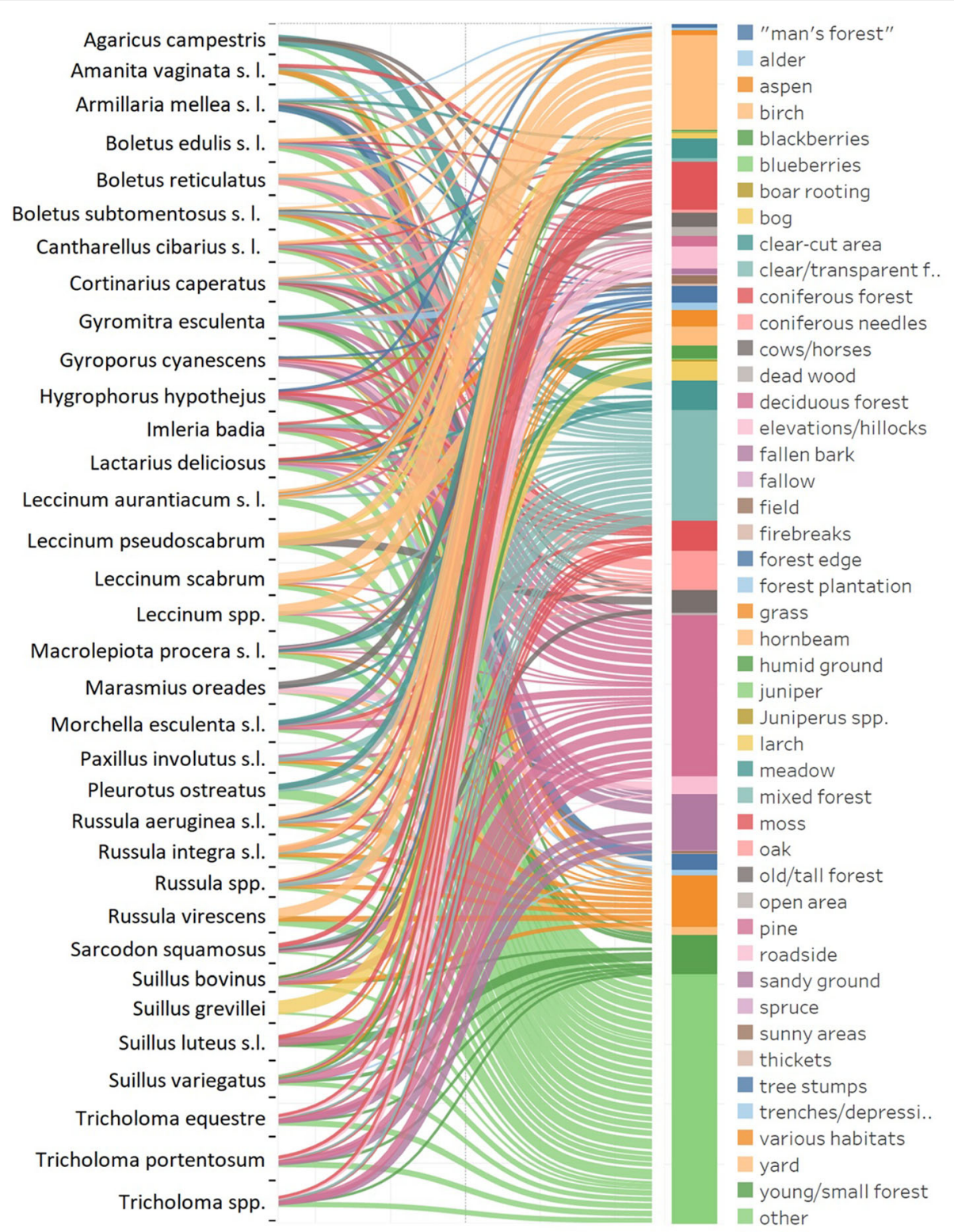

Fig. 2 The main observed habitat types preferred by certain mushroom species according to local mushroom collectors in Mazovia, Poland. Colour shows details about habitat. Size of line indicates percentage of respondents mentioning certain habitat in a particular species description

The collected data allowed to group species according to seven macrohabitats (Table 2).

Figure 3 shows a clear correlation between open area habitats-such as fields, meadows, and roadsides-and particular species of fungi, such as the saprotrophic Marasmius oreades (Bolton) Fr., Agaricus campestris L. or Macrolepiota procera (Scop.) Singer. Leccinum Gray spp. is closely correlated with birch and early successional habitats containing grasses. The top right part of the graph groups species correlated with dry, sandy, and disturbed soils (for example species from Tricholoma (Fr.) Staude, Hygrophorus hypothejus (Fr.) Fr. or Gyromitra esculenta (Pers.) Fr.). Habitats such as pine and moss are positively correlated, and they group species characteristic for pine forests, for example species from the Suillus genus. Species positively correlated with mixed forest habitats, birch forests, and a large number of various habitats are Boletus subtomentosus L., Paxillus involutus (Batsch) Fr., or species from the Russula Pers. genus.

\section{Abundance changes of fungi perceived by local mushroom collectors}

Most respondents (53\%) observed a decrease of macrofungi abundance during their lifetime (10-50 years). Among them, 12 respondents (2\%) emphasized that the biggest drop in abundance of fruiting bodies occurred 


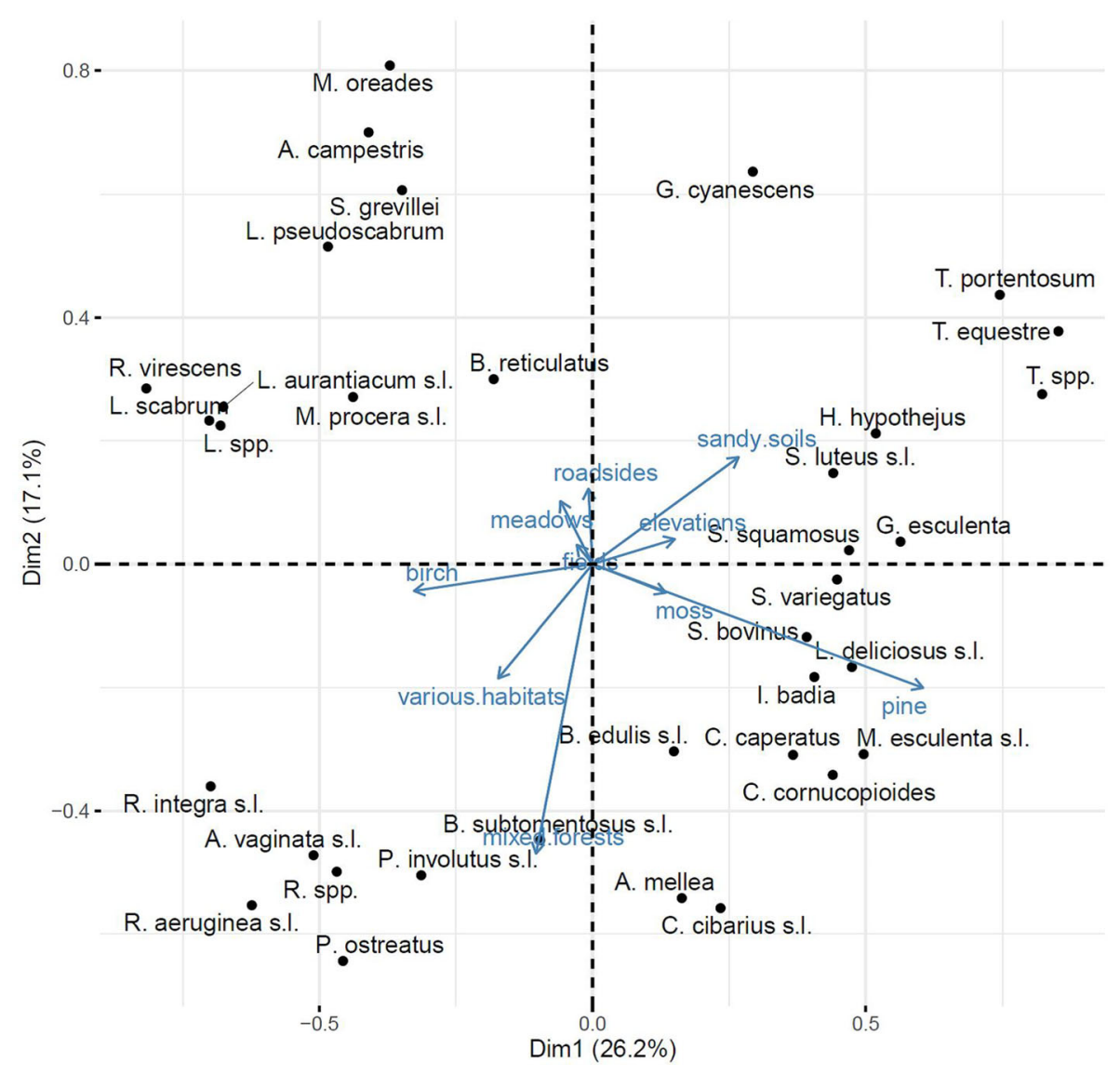

Fig. 3 PCA of taxa in relation to habitats most frequently mentioned by the respondents

during the last two decades. The $13 \%$ of respondents who noticed fluctuations in abundance attributed them to natural changes related to annual differences in yearly rainfall and temperatures. Over a third (34\%) of respondents did not notice any changes in fungal abundance. Only one person $(0.14 \%)$ noticed a steady increase of macrofungi abundance.

Respondents mainly focused on general abundance of edible macrofungi species. The general view on mushroom abundance emerged from the assumption that the majority of fungal species react to the same biotic and abiotic stresses. According to the majority of reports, there has been a noticeable decrease in the abundance of all macrofungi in the whole Mazovia region (Fig. 4). This concerns especially the northern and western parts of the region, where over $70 \%$ of the respondents have noticed a decrease in macrofungal abundance. The main reason for abundance decrease listed by the informants is drought ( $n=186,27 \%$ of respondents). Reports of progressive drought negatively affecting fungal abundance were recorded in all 38 research localities. Other reasons were as follows: forest management $(n=30)$, climate change $(n=21)$, anthropopressure $(n=19)$, environmental pollution $(n=16)$, overgrowing habitats $(n=11)$, and wild boar activity $(n=5)$. Sixty respondents were not able to list the cause of declining macrofungal abundance.

The lowest percentage of decrease in fungal abundance (around 35\%) was recorded in the eastern part of the Mazovia region. In this area, the most often listed determinant of mushroom abundance decrease was forest habitats becoming overgrown by understory vegetation. In the north-eastern part of Mazovia, where the decrease in abundance is highest, respondents have declared that 'forest management' is the main cause of this phenomenon. In localities situated close to the southwest of the capital city, anthropopressure has been determined as the main cause of edible fungi abundance decrease. Aside from overall information on macrofungal abundance, some of the respondents also noted a significant decrease in the abundance of particular fungi species. Altogether, 27 independent respondents reported a significant decrease of Lactarius deliciosus (L.) Gray abundance, 19-a decrease of Boletus edulis Bull. abundance, 18-in species from the Tricholoma (Fr.) Staude genus. Additionally, 8 respondents recorded a significant 


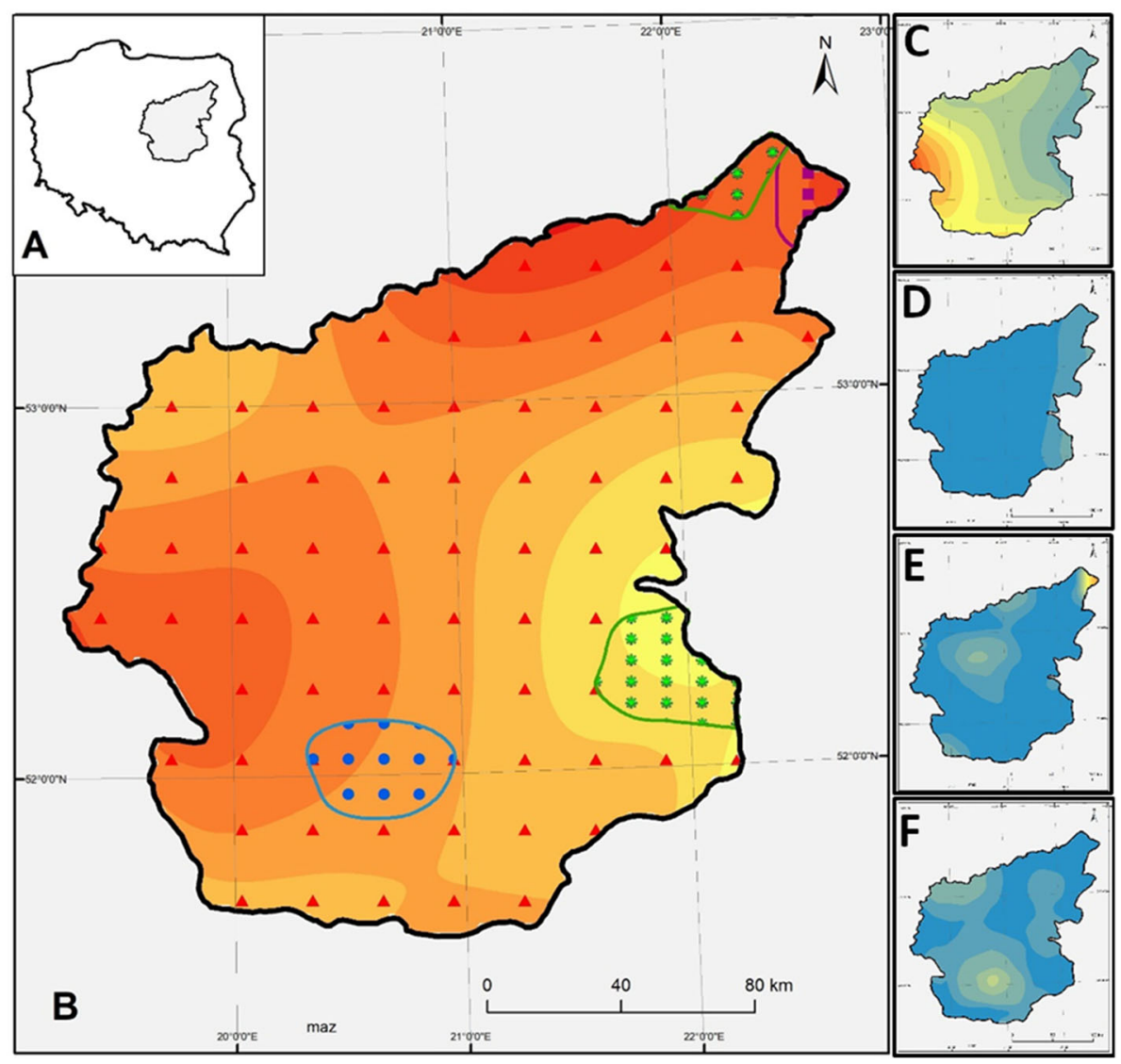

$\begin{array}{lllllllllllllll}0 \% & 5 \% & 10 \% & 15 \% & 20 \% & 25 \% & 30 \% & 35 \% & 40 \% & 45 \% & 50 \% & 55 \% & 60 \% & 65 \% & 70 \%\end{array}$

Dominant cause of macrofungal abundance decrease reported by the respondents:

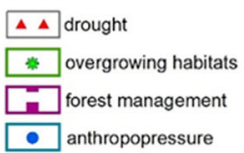

Fig. 4 Percentage of residents who have noticed a steady decrease in edible macrofungi abundance (a research area within the borders of Poland; $\mathbf{b}$ historical borders of the Mazovia region and the percentage of respondents that have indicated a steady decrease of macrofungal abundance during lifelong observations; c percentage of respondents who reported drought as the main cause of fungal abundance decrease; $\mathbf{d}$ percentage of respondents who reported habitat overgrowth as the main cause of fungal abundance decrease; e percentage of respondents who reported forest management as the main cause of fungal abundance decrease; $\mathbf{d}$ percentage of respondents who reported anthropopressure as the main cause of fungal abundance decrease)

decrease of Tricholoma equestre (L.) P. Kumm. abundance, 18-a decrease of Cantharellus cibarius Fr. abundance, 12-a decrease of Agaricus campestris L. abundance, and 10-a decrease of Suillus luteus (L.) Roussel abundance. An increased abundance of one species, Imleria badia (Fr.) Vizzini, has also been noted, with its increase reported by 15 independent respondents (Table 3).

\section{Discussion}

\section{Habitats listed to describe habitat preference}

While describing fungi habitats, mushroom collectors mentioned 98 habitat types, of which most were meso- and microhabitats. Local ethnoecological knowledge on fungi was formed at a finer spatial scale than knowledge concerning plant ethnoecology documented in previous research $[10,15,16]$.

Respondents usually described tree species only to the genus level. The respondents gave detailed descriptions of forest communities relatively rarely. However, they mentioned some very specific fungal habitats like hillocks, firebrakes, self-sown forests, specific litter layer composition, or relevant tree species, as these features enable them to specify the landscape in which they usually look for certain species of fungi, implementing high complexity of folk knowledge related to fungal ecology. 
Table 2 Fungi habitat preferences according to the interviewees (Mazovia, Poland)

\begin{tabular}{|c|c|c|c|c|c|c|}
\hline Grasslands & $\begin{array}{l}\text { Forest } \\
\text { clearcutting }\end{array}$ & $\begin{array}{l}\text { Semi-open and light } \\
\text { forest }\end{array}$ & Various habitats & Deciduous forest & Coniferous forest & Mixed forests \\
\hline $\begin{array}{l}\text { Agaricus } \\
\text { campestris }\end{array}$ & Armillaria mellea & Boletus edulis & Amanita vaginata & Armillaria mellea & Armillaria mellea & Amanita vaginata \\
\hline $\begin{array}{l}\text { Macrolepiota } \\
\text { procera }\end{array}$ & $\begin{array}{l}\text { Gyromitra } \\
\text { esculenta }\end{array}$ & Boletus subtomentosus & $\begin{array}{l}\text { Boletus } \\
\text { subtomentosus }\end{array}$ & Boletus edulis & Boletus edulis & Boletus edulis \\
\hline \multirow[t]{21}{*}{$\begin{array}{l}\text { Marasmius } \\
\text { oreades }\end{array}$} & Morchella spp. & Lactarius deliciosus & $\begin{array}{l}\text { Cantharellus } \\
\text { cibarius }\end{array}$ & Boletus reticulatus & $\begin{array}{l}\text { Cantharellus } \\
\text { cibarius }\end{array}$ & Boletus reticulatus \\
\hline & $\begin{array}{l}\text { Pleurotus } \\
\text { ostreatus }\end{array}$ & Leccinum scabrum & Leccinum scabrum & Cantharellus cibarius & $\begin{array}{l}\text { Cortinarius } \\
\text { caperatus }\end{array}$ & $\begin{array}{l}\text { Boletus } \\
\text { subtomentosus }\end{array}$ \\
\hline & & Macrolepiota procera & $\begin{array}{l}\text { Macrolepiota } \\
\text { procera }\end{array}$ & Leccinum aurantiacum & Gyromitra esculenta. & Cantharellus cibarius \\
\hline & & Paxillus involutus & Paxillus involutus & $\begin{array}{l}\text { Leccinellum } \\
\text { pseudoscabrum }\end{array}$ & $\begin{array}{l}\text { Gyroporus } \\
\text { cyanescens }\end{array}$ & Cortinarius caperatus \\
\hline & & Russula spp. & Russula spp. & Leccinum scabrum & $\begin{array}{l}\text { Hygrophorus } \\
\text { hypothejus }\end{array}$ & $\begin{array}{l}\text { Craterellus } \\
\text { cornucopioides }\end{array}$ \\
\hline & & Suillus bovinus & Suillus bovinus & Leccinum scabrum & Imleria badia & Gyromitra esculenta \\
\hline & & & & Paxillus involutus & Lactarius deliciosus & $\begin{array}{l}\text { Gyroporus } \\
\text { cyanescens }\end{array}$ \\
\hline & & & & Russula spp. & Morchella spp. & Imleria badia \\
\hline & & & & & Paxillus involutus & Lactarius deliciosus \\
\hline & & & & & Russula spp. & $\begin{array}{l}\text { Leccinum } \\
\text { aurantiacum }\end{array}$ \\
\hline & & & & & $\begin{array}{l}\text { Sarcodon } \\
\text { squamosus }\end{array}$ & Leccinum scabrum \\
\hline & & & & & Suillus bovinus & Macrolepiota procera \\
\hline & & & & & Suillus grevillei & Morchella spp. \\
\hline & & & & & Suillus luteus & Paxillus involutus \\
\hline & & & & & Suillus variegatus & Pleurotus ostreatus \\
\hline & & & & & Tricholoma equestre & Russula spp. \\
\hline & & & & & $\begin{array}{l}\text { Tricholoma } \\
\text { portentosum }\end{array}$ & Sarcodon squamosus \\
\hline & & & & & & Suillus bovinus \\
\hline & & & & & & Suillus variegatus \\
\hline & & & & & & Tricholoma equestre \\
\hline & & & & & & $\begin{array}{l}\text { Tricholoma } \\
\text { portentosum }\end{array}$ \\
\hline
\end{tabular}

On the other hand, in folk ecology descriptions, we can find recurring habitat characteristics that are still not scientifically evaluated in depth in relation to fungi occurrence. These include exposure to sun (mentioned particularly often), the shape of the terrain, or litter thickness. Such indicators were very often perceived as crucial during the description of particular fungi species habitats. This information may provide new guidelines that could determine the direction of further studies on ecology of local fungi.

Respondents determined habitats using diverse dimensions (see section "Habitats listed by locals to describe habitat preference of mushroom species"). Studies conducted with other local communities show that these dimensions are shaped by different environments that make them characteristic for certain local groups [15]. When comparing dimensions used to determine fungal habitats with dimensions used by different communities, we can notice some similarities. The most important dimensions recorded in the present study, such as dominant species, land-use type, or vegetation structure, are characteristic for local communities living in the Carpathians and are less important to people living in Western Canada or Mongolia [16]. This suggests similarities in habitat perception between Central European communities that are worthy of further investigation. 
Table 3 Habitat preferences and abundance changes of selected fungal taxa.

\begin{tabular}{|c|c|c|c|c|c|c|}
\hline \multirow[t]{2}{*}{ Species } & \multirow[t]{2}{*}{ Habitat } & \multirow{2}{*}{$\begin{array}{l}\text { Habitat } \\
\text { (n) }\end{array}$} & \multicolumn{4}{|c|}{ Abundance changes } \\
\hline & & & Increase $(n)$ & Increase cause & Decrease $(n)$ & Decrease cause \\
\hline \multirow[t]{17}{*}{ Macromycetes general } & Table 1 & Table 1 & 1 & Imprecise & 186 & Drought \\
\hline & & & & & 60 & Imprecise \\
\hline & & & & & 30 & Forest management \\
\hline & & & & & 21 & Climate changes \\
\hline & & & & & 19 & Antropopression (general) \\
\hline & & & & & 16 & Pollution \\
\hline & & & & & 11 & Habitat overgrowing \\
\hline & & & & & 10 & Mycelium/litter damage \\
\hline & & & & & 3 & Boars \\
\hline & & & & & 3 & Grazing abandonment \\
\hline & & & & & 3 & Low night temperatures \\
\hline & & & & & 2 & Incorrect collection \\
\hline & & & & & 2 & Urbanization \\
\hline & & & & & 2 & Increased pest activities \\
\hline & & & & & 1 & Logging \\
\hline & & & & & 1 & Unraked litter \\
\hline & & & & & 1 & High night temperatures \\
\hline \multirow[t]{4}{*}{ Agaricus campestris s.l. } & Meadow & 104 & 0 & None & 12 & Grazing abandonment \\
\hline & Field & 31 & & & & \\
\hline & Cows/horses & 31 & & & & \\
\hline & Other & 29 & & & & \\
\hline \multirow[t]{4}{*}{ Amanita vaginata } & Various habitats & 6 & 0 & None & 1 & Forest management \\
\hline & Mixed forest & 5 & & & & \\
\hline & Coniferous forest & 3 & & & & \\
\hline & Other & 5 & & & & \\
\hline \multirow[t]{11}{*}{ Armillaria mellea s.l. } & Tree stumps & 100 & 0 & None & 2 & Imprecise \\
\hline & Old/tall forest & 20 & & & & \\
\hline & Clearcut area & 18 & & & & \\
\hline & Pine & 17 & & & & \\
\hline & Young/small forest & 16 & & & & \\
\hline & Deciduous forest & 12 & & & & \\
\hline & Dead wood & 12 & & & & \\
\hline & Humid ground & 10 & & & & \\
\hline & Oak & 9 & & & & \\
\hline & Alder & 7 & & & & \\
\hline & Other & 61 & & & & \\
\hline \multirow[t]{7}{*}{ Boletus edulis s.l. } & Oak & 194 & 0 & None & 9 & Imprecise \\
\hline & Pine & 158 & & & 6 & Drought \\
\hline & Mixed forest & 102 & & & 2 & Pollution \\
\hline & Birch & 90 & & & 1 & Antropopression (general) \\
\hline & Coniferous forest & 32 & & & 1 & Forest management \\
\hline & Forest edge & 30 & & & & \\
\hline & Deciduous forest & 26 & & & & \\
\hline
\end{tabular}


Table 3 Habitat preferences and abundance changes of selected fungal taxa. (Continued)

\begin{tabular}{|c|c|c|c|c|c|c|}
\hline \multirow[t]{2}{*}{ Species } & \multirow[t]{2}{*}{ Habitat } & \multirow{2}{*}{$\begin{array}{l}\text { Habitat } \\
(n)\end{array}$} & \multicolumn{4}{|c|}{ Abundance changes } \\
\hline & & & Increase $(n)$ & Increase cause & Decrease $(n)$ & Decrease cause \\
\hline & Old/tall forest & 26 & & & & \\
\hline & Other & 189 & & & & \\
\hline \multirow[t]{5}{*}{ Boletus reticulatus } & Oak & 13 & 0 & None & 0 & None \\
\hline & Sandy ground & 5 & & & & \\
\hline & Birch & 3 & & & & \\
\hline & Mixed forest & 2 & & & & \\
\hline & Other & 4 & & & & \\
\hline \multirow[t]{8}{*}{ Boletus subtomentosus s.l. } & Mixed forest & 27 & 0 & None & 1 & Imprecise \\
\hline & Pine & 15 & & & & \\
\hline & Various habitats & 14 & & & & \\
\hline & Birch & 9 & & & & \\
\hline & Moss & 5 & & & & \\
\hline & Forest edge & 4 & & & & \\
\hline & Grasses & 4 & & & & \\
\hline & Other & 42 & & & & \\
\hline \multirow[t]{10}{*}{ Cantharellus cibarius s.l. } & Mixed forest & 106 & 0 & None & 13 & Imprecise \\
\hline & Pine & 99 & & & 5 & Drought \\
\hline & Birch & 64 & & & & \\
\hline & Oak & 43 & & & & \\
\hline & Moss & 37 & & & & \\
\hline & Sandy ground & 35 & & & & \\
\hline & Coniferous forest & 32 & & & & \\
\hline & Deciduous forest & 20 & & & & \\
\hline & Various habitats & 20 & & & & \\
\hline & Other & 127 & & & & \\
\hline \multirow[t]{9}{*}{ Cortinarius caperatus } & Pine & 32 & 0 & None & 2 & Drought \\
\hline & Moss & 20 & & & 1 & Forest management \\
\hline & Mixed forest & 16 & & & 1 & Imprecise \\
\hline & Coniferous needles & 16 & & & & \\
\hline & Old/tall forest & 12 & & & & \\
\hline & Birch & 8 & & & & \\
\hline & Sunny areas & 8 & & & & \\
\hline & Clear/transparent forest & 8 & & & & \\
\hline & Other & 52 & & & & \\
\hline \multirow[t]{3}{*}{ Craterellus cornucopoides } & Pine & 4 & 0 & None & 2 & Imprecise \\
\hline & Oak & 4 & & & & \\
\hline & Mixed forest & 2 & & & & \\
\hline \multirow[t]{6}{*}{ Gyromitra esculenta } & Pine & 10 & 0 & None & 0 & None \\
\hline & Forest plantation & 8 & & & & \\
\hline & Young/small forest & 5 & & & & \\
\hline & Clearcut area & 4 & & & & \\
\hline & Sandy ground & 3 & & & & \\
\hline & Mixed forest & 2 & & & & \\
\hline
\end{tabular}


Table 3 Habitat preferences and abundance changes of selected fungal taxa. (Continued)

\begin{tabular}{|c|c|c|c|c|c|c|}
\hline \multirow[t]{2}{*}{ Species } & \multirow[t]{2}{*}{ Habitat } & \multirow{2}{*}{$\begin{array}{l}\text { Habitat } \\
(n)\end{array}$} & \multicolumn{4}{|c|}{ Abundance changes } \\
\hline & & & Increase $(n)$ & Increase cause & Decrease $(n)$ & Decrease cause \\
\hline & Firebreaks & 2 & & & & \\
\hline & Other & 6 & & & & \\
\hline \multirow[t]{10}{*}{ Gyroporus cyanescens } & Sandy ground & 21 & 0 & None & 2 & Imprecise \\
\hline & Pine & 7 & & & & \\
\hline & Roadside & 6 & & & & \\
\hline & Oak & 4 & & & & \\
\hline & Yard & 4 & & & & \\
\hline & Forest edge & 3 & & & & \\
\hline & Young/small forest & 3 & & & & \\
\hline & Juniperus spp. & 2 & & & & \\
\hline & Moss & 2 & & & & \\
\hline & Other & 2 & & & & \\
\hline \multirow[t]{6}{*}{ Hygrophorus hypothejus } & Pine & 9 & 0 & None & 0 & None \\
\hline & Coniferous forest & 3 & & & & \\
\hline & Young/small forest & 3 & & & & \\
\hline & Moss & 2 & & & & \\
\hline & 'Man's forest' & 2 & & & & \\
\hline & Other & 6 & & & & \\
\hline \multirow[t]{6}{*}{ Imleria badia } & Pine & 200 & 15 & Imprecise & 2 & Imprecise \\
\hline & Mixed forest & 82 & & & & \\
\hline & Moss & 61 & & & & \\
\hline & Coniferous forest & 51 & & & & \\
\hline & Various habitats & 20 & & & & \\
\hline & Other & 163 & & & & \\
\hline \multirow[t]{12}{*}{ Lactarius deliciosus s.l. } & Grasses & 29 & 0 & None & 16 & Drought \\
\hline & Pine & 24 & & & 8 & Imprecise \\
\hline & Forest edge & 15 & & & 2 & Forest management \\
\hline & Meadow & 15 & & & 1 & Pollution \\
\hline & Mixed forest & 14 & & & & \\
\hline & Trenches/depressions & 14 & & & & \\
\hline & Coniferous forest & 12 & & & & \\
\hline & Spruce & 10 & & & & \\
\hline & Oak & 7 & & & & \\
\hline & Moss & 7 & & & & \\
\hline & Humid ground & 7 & & & & \\
\hline & Other & 50 & & & & \\
\hline \multirow[t]{6}{*}{ Leccinum aurantiacum s.l. } & Birch & 175 & 0 & None & 3 & Drought \\
\hline & Aspen & 69 & & & 1 & Pollution \\
\hline & Mixed forest & 33 & & & & \\
\hline & Deciduous forest & 26 & & & & \\
\hline & Alder & 15 & & & & \\
\hline & Other & 121 & & & & \\
\hline Leccinum pseudoscabrum & Hornbeam & 7 & 0 & & 3 & Imprecise \\
\hline
\end{tabular}


Table 3 Habitat preferences and abundance changes of selected fungal taxa. (Continued)

\begin{tabular}{|c|c|c|c|c|c|c|}
\hline \multirow[t]{2}{*}{ Species } & \multirow[t]{2}{*}{ Habitat } & \multirow{2}{*}{$\begin{array}{l}\text { Habitat } \\
\text { (n) }\end{array}$} & \multicolumn{4}{|c|}{ Abundance changes } \\
\hline & & & Increase $(n)$ & Increase cause & Decrease $(n)$ & Decrease cause \\
\hline & Old/tall forest & 4 & & & & \\
\hline & Humid ground & 2 & & & & \\
\hline & Bog & 2 & & & & \\
\hline & Birch & 2 & & & & \\
\hline & Other & 3 & & & & \\
\hline \multirow[t]{6}{*}{ Leccinum scabrum } & Birch & 195 & 0 & None & 1 & Imprecise \\
\hline & Mixed forest & 38 & & & 1 & Drought \\
\hline & Grass & 16 & & & & \\
\hline & Pine & 14 & & & & \\
\hline & Various habitats & 14 & & & & \\
\hline & Other & 97 & & & & \\
\hline \multirow[t]{5}{*}{ Leccinum spp. } & Birch & 137 & 0 & None & 2 & Drought \\
\hline & Mixed forest & 29 & & & & \\
\hline & Oak & 14 & & & & \\
\hline & Pine & 11 & & & & \\
\hline & Other & 99 & & & & \\
\hline \multirow[t]{11}{*}{ Macrolepiota procera } & Meadow & 78 & 0 & None & 1 & Imprecise \\
\hline & Forest edge & 50 & & & & \\
\hline & Field & 36 & & & & \\
\hline & Mixed forest & 33 & & & & \\
\hline & Various habitats & 19 & & & & \\
\hline & Open area & 16 & & & & \\
\hline & Grasses & 13 & & & & \\
\hline & Roadsides & 12 & & & & \\
\hline & Pine & 11 & & & & \\
\hline & Fallow & 10 & & & & \\
\hline & Other & 91 & & & & \\
\hline \multirow[t]{6}{*}{ Marasmius oreades } & Roadside & 16 & 0 & None & 2 & Grazing abandonment \\
\hline & Cows/horses & 13 & & & & \\
\hline & Yard & 7 & & & & \\
\hline & Meadow & 4 & & & & \\
\hline & Trenches/depressions & 2 & & & & \\
\hline & Other & 8 & & & & \\
\hline \multirow[t]{7}{*}{ Morchella esculenta s.l. } & Pine & 5 & 0 & None & 2 & Habitat overgrowing \\
\hline & Clear-cut area & 3 & & & & \\
\hline & Fallen bark & 3 & & & & \\
\hline & Oak & 2 & & & & \\
\hline & Mixed forest & 2 & & & & \\
\hline & Moss & 2 & & & & \\
\hline & Other & 4 & & & & \\
\hline \multirow[t]{3}{*}{ Paxillus involutus s.l. } & Mixed forest & 20 & 0 & None & 4 & Drought \\
\hline & Various habitat & 12 & & & 1 & imprecise \\
\hline & Pine & 7 & & & & \\
\hline
\end{tabular}


Table 3 Habitat preferences and abundance changes of selected fungal taxa. (Continued)

\begin{tabular}{|c|c|c|c|c|c|c|}
\hline \multirow[t]{2}{*}{ Species } & \multirow[t]{2}{*}{ Habitat } & \multirow{2}{*}{$\begin{array}{l}\text { Habitat } \\
(n)\end{array}$} & \multicolumn{4}{|c|}{ Abundance changes } \\
\hline & & & Increase $(n)$ & Increase cause & Decrease $(n)$ & Decrease cause \\
\hline & Deciduous forest & 4 & & & & \\
\hline & Other & 15 & & & & \\
\hline \multirow[t]{4}{*}{ Pleurotus ostreatus } & Mixed forest & 2 & 0 & None & 0 & None \\
\hline & Dead wood & 2 & & & & \\
\hline & Clear-cut area & 2 & & & & \\
\hline & Other & 4 & & & & \\
\hline \multirow[t]{8}{*}{ Russula aeruginea s.l. } & Mixed forest & 13 & 0 & None & 2 & Imprecise \\
\hline & Various habitats & 9 & & & 1 & Drought \\
\hline & Birch & 7 & & & & \\
\hline & Coniferous forest & 4 & & & & \\
\hline & Pine & 3 & & & & \\
\hline & Forest edge & 2 & & & & \\
\hline & Grass & 2 & & & & \\
\hline & Other & 7 & & & & \\
\hline \multirow[t]{5}{*}{ Russula integra s.l. } & Birch & 3 & 0 & None & 0 & None \\
\hline & Coniferous forest & 2 & & & & \\
\hline & Various habitats & 2 & & & & \\
\hline & Mixed forest & 2 & & & & \\
\hline & Other & 2 & & & & \\
\hline \multirow[t]{3}{*}{ Russula virescens } & Birch & 4 & 0 & None & 2 & Imprecise \\
\hline & Various habitats & 2 & & & & \\
\hline & Other & 4 & & & & \\
\hline \multirow[t]{9}{*}{ Russula spp. } & Mixed forest & 22 & 0 & None & 2 & Drought \\
\hline & Various habitats & 11 & & & 1 & Antropopression (general) \\
\hline & Pine & 4 & & & 1 & Imprecise \\
\hline & Birch & 4 & & & & \\
\hline & Coniferous forest & 3 & & & & \\
\hline & Deciduous forest & 3 & & & & \\
\hline & Oak & 3 & & & & \\
\hline & Grasses & 3 & & & & \\
\hline & Other & 10 & & & & \\
\hline \multirow[t]{6}{*}{ Sarcodon squamosus } & Pine & 14 & 0 & None & 2 & Drought \\
\hline & Coniferous forest & 8 & & & 2 & Forest management \\
\hline & Old/tall forest & 8 & & & 1 & Imprecise \\
\hline & Elevations/hillocs & 5 & & & & \\
\hline & Mixed forest & 3 & & & & \\
\hline & Other & 3 & & & & \\
\hline \multirow[t]{6}{*}{ Suillus bovinus } & Pine & 15 & 0 & None & 1 & Drought \\
\hline & Various habitats & 7 & & & 1 & Imprecise \\
\hline & Mixed forest & 4 & & & & \\
\hline & Young/small forest & 4 & & & & \\
\hline & Forest edge & 3 & & & & \\
\hline & Elevations/hillocks & 3 & & & & \\
\hline
\end{tabular}


Table 3 Habitat preferences and abundance changes of selected fungal taxa. (Continued)

\begin{tabular}{|c|c|c|c|c|c|c|}
\hline \multirow[t]{2}{*}{ Species } & \multirow[t]{2}{*}{ Habitat } & \multirow{2}{*}{$\begin{array}{l}\text { Habitat } \\
(n)\end{array}$} & \multicolumn{4}{|c|}{ Abundance changes } \\
\hline & & & Increase $(n)$ & Increase cause & Decrease $(n)$ & Decrease cause \\
\hline & Grasses & 3 & & & & \\
\hline & Coniferous forest & 2 & & & & \\
\hline & Moss & 2 & & & & \\
\hline & Blackberries & 2 & & & & \\
\hline & Humid ground & 2 & & & & \\
\hline & Boar rooting & 2 & & & & \\
\hline & Other & 6 & & & & \\
\hline \multirow[t]{2}{*}{ Suillus grevillei } & Larch & 12 & 0 & None & 0 & None \\
\hline & Other & 1 & & & & \\
\hline \multirow[t]{6}{*}{ Suillus luteus s.l. } & Pine & 239 & 0 & None & 5 & Imprecise \\
\hline & Young/small forest & 204 & & & 3 & Drought \\
\hline & Coniferous forest & 78 & & & 2 & Antropopression (general) \\
\hline & Grasses & 20 & & & & \\
\hline & Thickets & 19 & & & & \\
\hline & Other & 112 & & & & \\
\hline \multirow[t]{14}{*}{ Suillus variegatus } & Pine & 19 & 0 & None & 1 & Imprecise \\
\hline & Humid ground & 7 & & & & \\
\hline & Young/small forest & 7 & & & & \\
\hline & Mixed forest & 5 & & & & \\
\hline & Coniferous forest & 4 & & & & \\
\hline & Moss & 4 & & & & \\
\hline & Deciduous forest & 2 & & & & \\
\hline & Juniper & 2 & & & & \\
\hline & Elevations/hillocks & 2 & & & & \\
\hline & Grasses & 2 & & & & \\
\hline & Blueberries & 2 & & & & \\
\hline & Clear/transparent forest & 2 & & & & \\
\hline & Trenches/depressions & 2 & & & & \\
\hline & Other & 10 & & & & \\
\hline \multirow[t]{8}{*}{ Tricholoma equestre } & Sandy ground & 82 & 0 & None & 5 & Imprecise \\
\hline & Pine & 78 & & & 2 & Antropopression (general) \\
\hline & Elevations/hillocks & 47 & & & 1 & Habitat overgrowing \\
\hline & Coniferous forest & 21 & & & & \\
\hline & Young/small forest & 20 & & & & \\
\hline & Moss & 19 & & & & \\
\hline & Mixed forest & 12 & & & & \\
\hline & Other & 61 & & & & \\
\hline \multirow[t]{6}{*}{ Tricholoma portentosum } & Sandy ground & 77 & 0 & None & 1 & Antropopression (general) \\
\hline & Pine & 62 & & & 1 & Drought \\
\hline & Elevations/hillocks & 43 & & & 2 & Imprecise \\
\hline & Coniferous forest & 23 & & & & \\
\hline & Moss & 18 & & & & \\
\hline & Young/small forest & 18 & & & & \\
\hline
\end{tabular}


Table 3 Habitat preferences and abundance changes of selected fungal taxa. (Continued)

\begin{tabular}{|c|c|c|c|c|c|c|}
\hline \multirow[t]{2}{*}{ Species } & \multirow[t]{2}{*}{ Habitat } & \multirow{2}{*}{$\begin{array}{l}\text { Habitat } \\
\text { (n) }\end{array}$} & \multicolumn{4}{|c|}{ Abundance changes } \\
\hline & & & Increase $(n)$ & Increase cause & Decrease $(n)$ & Decrease cause \\
\hline & Mixed forest & 10 & & & & \\
\hline & Roadside & 10 & & & & \\
\hline & Other & 54 & & & & \\
\hline \multirow[t]{8}{*}{ Tricholoma spp. } & Pine & 124 & 0 & None & 10 & Imprecise \\
\hline & Sandy ground & 118 & & & 8 & Drought \\
\hline & Elevations/hillocks & 54 & & & & \\
\hline & Coniferous forest & 33 & & & & \\
\hline & Mixed forest & 28 & & & & \\
\hline & Young/small forest & 28 & & & & \\
\hline & Moss & 24 & & & & \\
\hline & Other & 79 & & & & \\
\hline
\end{tabular}

Respondents described coniferous forests as richer in fungi species than decidous forests. However, this is not reflected in scientific studies [39]. This result might be related to the composition of local forests. These forests are dominated by pine, which often creates monocultures and is included in mixed woodlands [31]. Therefore, coniferous forests are visited most often, which makes respondents more familiar with the composition of coniferous forest fungi.

\section{Observed habitat preference of mushroom species}

Data provided by scientific publications seldom displays information which habitat characteristics have the biggest importance for the development of a particular species. The large number of interviewees allows us to define the significance of particular habitat indicators based on the percentage of the most often mentioned characteristics.

By analysing the most frequently mentioned fungal habitats, we were able to create collective ethnoecological descriptions with characteristics comparable to scientific knowledge. Comparison of local folk habitat descriptions with the available scientific knowledge allowed us to select those observations which are present in scientific literature or need further investigation (Table 4).

The following folk observations correspond to already published scientific reports:

1. The importance of grazing areas and animal manure for the abundance of saprotrophic fungi such as Agaricus campestris L., Marasmius oreades (Bolton) Fr. and Macrolepiota procera (Scop.) Singer [40-43].
2. Leccinum scabrum's (Bull.) Gray preference for sylvopastoral habitats [39];

3. Armillaria (Fr.) Staude spp.'s preference towards living young pine trees-fungus' ability to produce fruiting bodies decreases with the age of the infected pine tree $[45,46]$;

4. Hygrophorus hypothejus' (Fr.) Fr., Suillus bovinus' (L.) Roussel, and Suillus luteus' (L.) Roussel preference towards young pine forest stands [48-52];

5. Boletus edulis' Bull., Cortinarius caperatus' (Pers.) Fr., Sarcodon squamosus' (Schaeff.) Quél. preference towards old forest stands [55-58];

6. Armillaria mellea's (Vahl) P. Kumm. s.l. need for relatively higher moisture than other wooddecaying basidiomycetes [60];

7. Higher abundance of Lactarius deliciosus (L.) Gray s.l. fruiting bodies in trenches and small depressions - the appropriate slope and elevation are significant predictors of Lactarius deliciosus (L.) Gray s.l. [66, 67];

8. Lactarius deliciosus' (L.) Gray complex requirement for high moisture in conjunction with access to strong sunlight $[47,66,68-70]$;

9. Suillus bovinus' (L.) Roussel preference for relatively higher moisture than other macrofungi [50, 71, 72];

10. Moss presence as one of the parameters potentially determining the habitat of Cantharellus cibarius Fr., Cortinarius caperatus (Pers.) Fr. and Suillus bovinus (L.) Roussel [61, 63, 73, 74];

11. Suillus bovinus (L.) Roussel and Suillus luteus (L.) Roussel fruiting bodies' occurrence on thin litter layer $[48,51,75]$;

12. Suillus variegatus (Sw.) Richon \& Roze fruiting bodies' occurrence on thick litter layer [76]; 
Table 4 Evaluation of reports of Polish mushroom collectors by present scientific mycological knowledge

\begin{tabular}{ll}
\hline Reports correspond with scientific literature & $\begin{array}{l}\text { Mentioned as possible in literature but not } \\
\text { yet tested }\end{array}$ \\
\hline $\begin{array}{l}\text { The importance of grazing areas and animal } \\
\text { manure for the abundance of saprotrophic fungi } \\
\text { such as Agaricus campestris, Marasmius oreades, } \\
\text { and Macrolepiota procera [40-43] }\end{array}$ & $\begin{array}{l}\text { The xerophillic character of Amanita vaginata. } \\
\text { Unconfirmed for A. vaginata but confirmed for } \\
\text { some species from the Vaginatae section [44] }\end{array}$ \\
$\begin{array}{ll}\text { Leccinum scabrum's preference for sylvopastoral } \\
\text { habitats [39] }\end{array}$ & $\begin{array}{l}\text { High amplitudes of litter temperature as a } \\
\text { stimulator of the production of fruiting bodies }\end{array}$ \\
$\begin{array}{ll}\text { Armillaria spp.'s preference towards living on } \\
\text { young pine trees - the fungus' ability to produce } \\
\text { fruiting bodies decreases with the age of the } \\
\text { infected pine tree [45, 46] }\end{array}$ & $\begin{array}{l}\text { Low canopy density and exposure of litter to sun } \\
\text { stimulating the fruiting of Cortinarius caperatus }\end{array}$ \\
$\begin{array}{l}\text { Hygrophorus hypothejus', Suillus bovinus', and } \\
\text { Suillus luteus' preference towards young pine } \\
\text { forest stands [48-52] }\end{array}$ & $\begin{array}{l}\text { Higher presence of Pleurotus ostreatus in cutting } \\
\text { and managed areas [53, 54] }\end{array}$ \\
$\begin{array}{l}\text { Boletus edulis', Cortinarius caperatus', Sarcodon } \\
\text { squamosus' preference towards old forest stands }\end{array}$ & $\begin{array}{l}\text { The positive effect of forest age on the } \\
\text { [55-58] }\end{array}$ \\
$\begin{array}{ll}\text { bodies [59] } \\
\text { Armillaria mellea's need for relatively higher } \\
\text { moisture than other wood-decaying basidiomy- } \\
\text { cetes [60] }\end{array}$ & $\begin{array}{l}\text { Influence of moss on the fungal fruiting process } \\
\text { (e.g. its protective effect, increasing soil nitrogen } \\
\text { and phosphorus content and being the source } \\
\text { of saprobiotic nutrition) [61-65] }\end{array}$
\end{tabular}

Not mentioned in literature and not yet tested

Higher abundance of Hygrophorus hypothejus's fruiting bodies in pine forests growing on former arable land than in ancient forest locations

Suillus bovinus, Tricholoma equestre and Tricholoma portentosum abundance is higher on uneven ground surface

\section{Litter density as one of the main factors} determining particular Suillus species fructification

Boar rooting as a stimulator of the production of Suillus bovinus fruiting bodies

The declining abundance of saprotrophic fungi in analysed areas as related to grazing abandonment and the use of synthetic fertilizers

Higher abundance of Lactarius deliciosus fruiting bodies in trenches and small depressions - the appropriate slope and elevation are significant predictors of Lactarius deliciosus $[66,67]$

Lactarius deliciosus' complex requirement for high moisture in conjunction with access to strong sunlight $[47,66,68-70]$

Suillus bovinus' preference for relatively higher moisture than other macrofungi $[50,71,72]$

Moss presence as one of the parameters potentially determining the habitat of Cantharellus cibarius, Cortinarius caperatus and Suillus bovinus $[61,63,73,74]$

Suillus bovinus and Suillus luteus fruiting bodies' occurrence on thin litter layer $[48,51,75]$

Suillus variegatus fruiting bodies' occurrence on thick litter layer [76]

Broken or ploughed forest cover inducing the production of Gyromitra esculenta and Morchella spp. ascocarps [77-80]]

Higher abundance of Boletus edulis, Boletus subtomentosus and Russulaceae fruiting bodies in lighter forest areas such as forest edges [81-83]

13. Broken or ploughed forest cover inducing the production of Gyromitra esculenta (Pers.) Fr. and Morchella Dill. ex Pers. spp. ascocarps [77-80];

14. Higher abundance of Boletus edulis Bull., Boletus subtomentosus L. and Russulaceae Lfruiting bodies in lighter forest areas such as forest edges [81-83].

Some phenomena observed by the informants have not yet been researched or tested by science, e.g.:
1. Higher abundance of Hygrophorus hypothejus's (Fr.) Fr. fruiting bodies in pine forests growing on former arable land than those in ancient forest locations;

2. Suillus bovinus (L.) Roussel, Tricholoma equestre (L.) P. Kumm. and Tricholoma portentosum (Fr.) Quél. abundance is higher on uneven ground surface;

3. Litter density as one of the main factors determining particular Suillus species fructification; 
4. Boar rooting as a stimulator of the production of Suillus bovinus (L.) Roussel fruiting bodies;

5. The declining abundance of saprotrophic fungi in analysed areas as related to grazing abandonment and the use of synthetic fertilizers.

Some phenomena mentioned by informants are known to many mycologists but have no scientific confirmation or were only suggested by some authors:

1. The xerophillic character of Amanita vaginata (Bull.) Lam. Unconfirmed for A. vaginata, but confirmed for some species from the Vaginatae section [44];

2. High amplitudes of litter temperature as a stimulator of the production of fruiting bodies;

3. Low canopy density and exposure of litter to sun stimulating the fruiting of Cortinarius caperatus (Pers.) Fr.-unconfirmed, but recent studies show its lower abundance in relatively high moisture conditions [47], which might be connected with low sun exposure;

4. Higher presence of Pleurotus ostreatus (Jacq.) P. Kumm. in cutting and managed areas; unconfirmed but suggested by a few authors (dead and damaged wood presence, wood inoculation) (e.g. [53, 54]);

5. The positive effect of forest age on the abundance of production of fungal fruiting bodies; mainly unexplored with one publication contradicting it [59];

6. Influence of moss on fungal fruiting process (e.g. protective effect, increasing soil nitrogen and phosphorus content and source of saprobiotic nutrition); mostly unexplored but suggested by [61-65].

\section{Perceived abundance change of mushrooms}

Mushroom collectors had the general perception that the decrease of mushroom abundance is the general trend in the areas they visit to collect mushrooms. The steady decrease of macrofungal abundance in Europe was already noticed in the 1970s [84-86]. At the beginning of the 1990s, scientists started to talk about the Mass Extinction of European Fungi [87, 88]. However, this tendency was formulated only on the basis of single reports, without presentation of any statistical figures [89].

The extensive research on the decline in the abundance of macrofungi was initiated at the end of the 1980s by the Dutch scientist, Eef Arnolds. The declining abundance of saprotrophic species occurring in the grasslands has been recorded mostly in connection to the newly implemented agricultural practices and use of artificial fertilizers [89]. A similar correlation has also been noticed by people living in Mazovia. When reporting on the abundance decrease of the field mushroom (Agaricus campestris L.) (12 persons), respondents stated grazing abandonment, changes in agricultural practices, and application of artificial fertilizers as the main causes of their decline. Arnolds [89] noticed a significant abundance decrease of 55 out of 126 analysed fungal species. It was mainly related to species characteristic of coniferous forests, which is the dominating type of forest in Mazovia (64\%). Air and soil pollution were taken to be the main cause of the decreasing abundance of macrofungi [89-91]. Arnolds based his research on long-term field observations preceding data analysis (1912-1954 and 1973-1982 as well as data collected during two decades of individual research preceding its publication). The results of the analysis showed a drop in the number of macrofungi species occurring in the Netherlands from 37 to 12 per $1000 \mathrm{~m}^{2}$. Similarly, as in case of studies contacted in Mazovia, Arnolds [89] observed that species which suffered the most significant decrease belonged to the Lactarius, Cantharellus, Boletus, Tricholoma, and Suillus genus. According to his studies, the biggest abundance decrease is observed among ectomycorrhizal fungi species-a group to which the majority of species mentioned in present work belong to. However, Arnolds did not take the gradual changes occurring in soil water regimes into consideration. According to recent studies on soil water content changes, in the last few decades we have been dealing with a gradual decrease of soil water content in Poland [91-93]. Respondents, too, listed it as one of the main reasons for the decrease in fungal abundance in Mazovian forests (Fig. 4).

Current studies also confirm Arnolds' reports on the visible decrease of macrofungi abundance. Research from Norway [94] confirms the significantly negative influence of nitrogen fertilization on the occurrence of fungal fruiting bodies. However, the same research also shows a high influence of drought on the decrease in the production of fruiting bodies. Studies conducted in northern Spain proved that partial rain exclusion ($30 \%)$ lowered the production of fungal fruiting bodies by 60\% [95]. De Aragón et al. [96] noticed that the right balance between accumulated monthly mean precipitation and evapotranspiration was of the greatest importance for macrofungi occurrence.

It was established that the main indicators of basidiomycetes' fruiting bodies presence are soil moisture and its temperature back in the mid-20th century [97]. Certain levels of these indicators have to occur simultaneously for a period of time relevant to the particular species. While all different species depend on different ranges of temperature, all species rely on an increased level of soil moisture. Dahlberg [98] showed that similar weather conditions can determine the 
production of $55-88 \%$ fruiting bodies of basidiomycetes species (after [94]).

The impact of climate change on fungi is scientifically indisputable. Gange [99] conducted 56-year-long research on the period of macrofungal fructification. Data collected on 315 different species shows a tendency for the average first date of fructification to come earlier in the year as time goes on, while the average last fruiting date now occurs significantly later. In his studies on climate change, Schär et al. [100] focused not on the gradual rise of temperatures, but on increasing temperature variability in Central Europe. According to his observations, one of the main results of this phenomenon is summer droughts such as the one which occurred in Poland in 2003 [101]. The progressive drought observed by the respondents, with its impact on changes in local mycobiota, might be related to scientifically observed changes in climate.

It has been recognized that the act of mushroom picking has no significant impact on macrofungal fruiting body abundance [102]. Mycorrhiza compression, on the other hand, can have a large impact on the occurrence of fruiting bodies. During present research, 10 independent respondents noticed a relationship between lower numbers of mushrooms and the introduction of heavy machinery to forest management. According to their reports, the abundance of fungal fruiting bodies decreased after band-saw operators were replaced with devices equipped with felling heads. The highly negative impact of the pressure of heavy machinery on forest litter layer has been confirmed by Arnolds [91] and Frey [103]. The correlation between heavy machinery use and mushroom abundance decrease is so significant that it is visible to a respondent's naked eye. Therefore, it is important to conduct further studies on the scale of this problem and to search for a new solution to be implemented in forest management. The decrease in fungal abundance could be also related to disturbances in the environmental nitrogen cycle as a result of artificial manure use, as confirmed by Vitousek [104].

The increased abundance of Imleria badia (Fr.) Vizzini, as observed by 15 respondents, can be explained by the Bay Bolete's high capacity to adapt to habitats with acidic soils [105]. This type of soil dominates in pine forests-the main forest type in Mazovia. The research conducted in European countries by Rosinger el al [106]. shows that species such as Xerocomus badius (Fr.) E.-J. Gilbert (currently Imleria badia (Fr.) Vizzini), Scleroderma citrinum Pers. and Paxillus involutus (Batsch) Fr. usually occur in areas that combine high annual temperature and low annual rainfall. This may also explain the higher Imleria badia occurrence. Furthermore, Clemmensen [107], Morgado [108], and Fernandez [109] classify the Bay Bolete to the group of long- distance exploration fungi. In other words, this species is able to create long rhizomorphs that enable efficient habitat penetration. Aside from improving its ability to explore, long rhizomorphs also improve water transportation and accumulation [110].

\section{Conclusions}

The interviewed Polish mushroom collectors had a deep understanding of fungal habitats. They used different scales of habitats to describe the habitat preferences of various fungi species. The high number of 98 fungal habitats listed by the respondents confirms the highly mycophillic character of people living in the studied area [34]. We found that some phenomena which have not yet been studied or tested by science were observed by multiple informants. Locals had the unanimous perception that fungal abundance is decreasing, and they identified drought as the key driver of the change.

We conclude that local ecological knowledge of lay mushroom collectors could offer new stimuli for scientific research and contribute to citizen-based monitoring of macrofungi.

Our large area study on fungal ethnoecology has a preliminary character and aims to encourage further research on this topic in other regions inhabited by mycophillic societies.

\section{Authors' contributions}

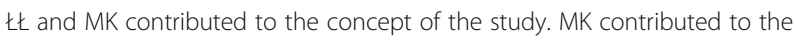
field work, data analysis, and first draft of the paper. ZM contributed to the analysis of folk habitat classification. All the authors contributed to the final draft. All authors read and approved the final manuscript.

\section{Funding}

The research was financed by funds from the National Science Centre (NCN) as part of the research project Preludium 2015/17/N/NZ9/00963.

Availability of data and materials

Voucher specimens for species were deposited in the herbarium of Warsaw University (WAW).

\section{Declarations}

\section{Ethics approval and consent to participate}

The methods of obtaining data during fieldwork followed guidelines set by International Society of Ethnobiology Code of Ethics [109] and the American Anthropological Association Code of Ethics [110] and adhere to the local traditions for such research. Prior oral informed consent was obtained from all study participants. No ethical committee permits were required. No permits were required to collect voucher specimens.

Consent for publication

Not applicable.

Competing interests

The authors declare that they have no competing interests.

\section{Author details}

${ }^{1}$ Institute of Ecology and Botany, Centre for Ecological Research, Vácrátót H-2163, Hungary. ${ }^{2}$ Botanical Garden Center for Biological Diversity Conservation in Powsin, Polish Academy of Sciences, Warsaw, Poland. ${ }^{3}$ Department of Botany, Faculty of Biotechnology, University of Rzeszów, Pigonia 1, 35-310 Rzeszów, Poland. 


\section{Received: 29 October 2020 Accepted: 1 April 2021 Published online: 21 April 2021}

\section{References}

1. Conklin HC. Hanunoo Agriculture. FAO Forestry Development Paper No. 12. Rome: Food and Agricultural Organization; 1957.

2. Anderson EN. Ethnobiology: overview of a growing field. In: Anderson EN, Pearsall DM, Hunn ES, Turner NJ, editors. Ethnobiology; 2011. p. 1-14. https://doi.org/10.1002/9781118015872.

3. Ingold T. The perception of the environment: essays on livelihood, dwelling and skill. London: Routledge.; 2002

4. Berkes F. Traditional ecological knowledge in perspective. In: Traditional ecological knowledge: concepts and cases (Vol. 1). Ottawa: Canadian Museum of Nature/International Development Research Centre; 1993.

5. Berlin EA, Berlin B. Medical ethnobiology of the Highland Maya of Chiapas, Mexico: the gastrointestinal diseases. 2015;10(2):271-3. https://doi.org/10.1 002/(sici)1520-6300(1998)10:2<271::aid-ajhb14>3.0.c0;2-5.

6. Nazarea VD, editor. Ethnoecology: situated knowledge/located lives.Tucson: University of Arizona Press; 1999.

7. Yamin-Pasternak S, Pasternak I. Ethnomycology. Int Encycl Anthropol. 2018 1-2. https://doi.org/10.1002/9781118924396.wbiea2088.

8. Huntington HP. Using traditional ecological knowledge in science: methods and applications. Ecol Appl. 2000;10(5):1270-4. https://doi.org/10.1890/10510761(2000)010[1270:UTEKIS]2.0.CO;2

9. Moller H, Berkes F, Lyver POB, Kislalioglu M. Combining science and traditional ecological knowledge: monitoring populations for $\mathrm{CO}^{-}$ management. Ecol Soc. 2004;9(3). https://doi.org/10.5751/es-00675-090302.

10. Molnár Z, Kis J, Vadász C, Papp L, Sándor I, Béres S, et al. Common and conflicting objectives and practices of herders and conservation managers: the need for a conservation herder. Ecosystem Health Sustainability. 2016; 2(4):e01215

11. Gantuya B, Avar Á, Babai D, Molnár Á, Molnár Z. "A herder's duty is to think": landscape partitioning and folk habitats of Mongolian herders in a mountain forest steppe (Khuvsugul-Murun region). J Ethnobiol Ethnomed. 2019;15(1):54.

12. Bürgi M, Bieling C, Von Hackwitz K, Kizos T, Lieskovský J, Martín MG, et al. Processes and driving forces in changing cultural landscapes across Europe. Landscape Ecol. 2017;32(11):2097-112. https://doi.org/10.1007/s10980-017-0513-z.

13. Kelemen E, Nguyen G, Gomiero T, Kovács E, Choisis JP, Choisis N, et al. Farmers' perceptions of biodiversity: lessons from a discourse-based deliberative valuation study. Land use Policy. 2013;35:318-28. https://doi. org/10.1016/j.landusepol.2013.06.005.

14. Nakashima D, KrupniEk I, Rubis JT, editors. Indigenous knowledge for climate change assessment and adaptation.Cambridge: Cambridge University Press; 2018.

15. Ujházy N, Molnár Z, Bede-Fazekas Á, Biró M. Do farmers and conservationists perceive landscape changes differently? Ecol Soc. 2020;25(3):12.

16. Ahnström J, Höckert J, Bergeå HL, Francis CA, Skelton P, Hallgren L. Farmers and nature conservation: What is known about attitudes, context factors and actions affecting conservation? Renew Agri Food Syst. 2009;24(1):38-47. https://doi.org/10.1017/S1742170508002391.

17. Gadgil M, Seshagiri Rao PR, Utkarsh G, Pramod P, Chhatre A. New meanings for old knowledge: the people's biodiversity registers program. Ecol Appl. 2000;10(5):1307-17. https://doi.org/10.1890/1051-0761(2000)010[13 07,NMFOKT]2.0.CO;2

18. Volpato G, Rossi D, Dentoni D. A reward for patience and suffering: ethnomycology and commodification of desert truffles among Sahrawi refugees and nomads of Western Sahara. Econ Bot. 2013;67(2):147-60. https://doi.org/10.1007/s12231-013-9234-7.

19. Trappe JM, Claridge AW, Claridge DL, Liddle L. Desert truffles of the Australian outback: ecology, ethnomycology, and taxonomy. Econ Bot. 2008;62(3):497-506. https://doi.org/10.1007/s12231-008-9041-8.

20. Lampman AM. Tzeltal ethnomycology: naming, classification and use of mushrooms in the highlands of Chiapas, Mexico. Georgia: Doctoral dissertation, University of Georgia; 2005.

21. Davies N. Boże igrzysko. Historia Polski. Kraków: Otwarte; 2012.

22. Pałucki W. Mazowsze w drugiej połowie XVI wieku. Warszaw: Państwowe Wydawnictwo Naukowe; 1973.

23. Główny Urząd Statystyczny. Bank Danych Lokalnych. 2018. Available at: https://bdl.stat.gov.pl/BDL/dane/podgrup/temat [cited 18.06.2018]
24. Kondracki J. Geografia regionalna Polski. Wydawn. Warszawa: Naukowe PWN; 2000.

25. Lorenc H. Atlas klimatu Polski. Warsaw: Instytut Meteorologii i Gospodarki Wodnej; 2005

26. European Environment Agency. Corine Land Cover 2012 Seamless Vector Data. 2017. Available at: https://www.eea.europa.eu/data-and-maps/data/ clc-2012-vector [cited 18.06.2018]

27. Braun K. Oblicze etnograficzne współczesnego województwa mazowieckiego. Rocznik Mazowiecki. 1999;11:39-55 http://mazowsze.hist. pl/17/Rocznik_Mazowiecki/383/1999/12958/.

28. Martin GJ. Ethnobotany: a methods manual. London: Routledge; 2010 https://doi.org/10.4324/9781849775854.

29. Kotowski MA, Pietras M, Łuczaj Ł. Extreme levels of mycophilia documented in Mazovia, a region of Poland. J Ethnobiol Ethnomed. 2019;15(1):12. https:// doi.org/10.1186/s13002-019-0291-6.

30. Albuquerque UP, Ramos MA, de Lucena RFP, Alencar NL. Methods and techniques used to collect ethnobiological data. In Methods and techniques in Ethnobiology and Ethnoecology. New York: Humana Press; 2014. p. 15-37. https://doi.org/10.1007/978-1-4614-8636-7.

31. Yamin-Pasternak S. Ethnomycology: fungi and mushrooms in cultural entanglements. In: Ethnobiology. New Jersey: Wiley; 2011. p. 213-30. https://doi.org/10.1002/9781118015872.ch13.

32. Lê S, Josse J, Husson F. FactoMineR: an R package for multivariate analysis. J Stat Softw. 2008;25(1, 1):-18. https://doi.org/10.18637/jss.v025.i01.

33. Gumińska B, Wojewoda W. Grzyby i ich oznaczanie. Warszawa: Państwowe Wydawnicto Rolnicze i Leśne; 1985.

34. Wojewoda W. Checklist of Polish Larger Basidiomycetes. Kraków: W. Szafer Institute of Botany-Polish Academy of Sciences; 2003.

35. Arora D. Mushrooms demystified. Berkeley: Ten Speed Press; 1986. https:// doi.org/ISBN0898151694

36. Crisan EV, Sands A, Chang ST, Hayes WA. The biology and cultivation of edible mushrooms. Nutri Value N Y Acad. 1978:251-93. https://doi.org/10.1 016/c2013-0-10484-9.

37. Gramss $\mathrm{G}$. The universe of basidiomycetous ground fungi. In: Current research, technology and education topics in applied microbiology and microbial biotechnology. Badajoz: Formatex; 2010. p. 218-29.

38. Ingold CT, Hudson HJ. Ecology of saprotrophic fungi. In: The Biology of Fungi. Dordrecht.: Springer; 1993. p. 145-57.

39. Abate D. Agaricus campestris in upland Ethiopia. Mycologist. 1999;13(1):28 https://doi.org/10.1016/S0269-915X(99)80075-5.

40. Shaw CG III, Roth LF. Control of Armillaria root rot in managed coniferous forests 1: a literature review. Eur J Forest Pathol. 1978;8(3):163-74. https:// doi.org/10.1111/j.1439-0329.1978.tb01463.x.

41. Termorshuizen AJ. Succession of mycorrhizal fungi in stands of Pinus sylvestris in the Netherlands. J Veg Sci. 1991;2(4):555-64. https://doi.org/1 $0.2307 / 3236038$.

42. Dahlberg A, Stenlid JAN. Size, distribution and biomass of genets in populations of Suillus bovinus (L.: Fr.) Roussel revealed by somatic incompatibility. New Phytol. 1994;128(2):225-34. https://doi.org/10.1111/j.14 69-8137.1994.tb04006.x.

43. Kubiak J. Wpływ różnych szczepionek mikoryzowych na wzrost sosny i liczbę pączków. Inżynieria Rolnicza. 2007;11:123-8.

44. Piškur B, Bajc M, Robek R, Humar M, Sinjur I, Kadunc A, et al. Influence of Pleurotus ostreatus inoculation on wood degradation and fungal colonization. Bioresource Technol. 2011;102(22):10611-7. https://doi.org/10.1 016/j.biortech.2011.09.008.

45. Babai D, Molnár Z. Multidimensionality and scale in a landscape ethnoecological partitioning of a mountainous landscape (Gyimes, Eastern Carpathians, Romania). J Ethnobiol Ethnomed. 2013;9(1):1-21. https://doi. org/10.1186/1746-4269-9-11.

46. Kałucka I. Macrofungi in the secondary succession on the abandoned farmland near the Białowieża old-growth forest. Monog Botan. 2009;99:1155. https://doi.org/10.5586/mb.2009.001.

47. Hurst J, Rutherford L. A gourmet's guide to mushrooms and truffles. London: Bedford Editions/Salamander Books Ltd; 1996.

48. Kałucka IL, Jagodziński AM. Successional traits of ectomycorrhizal fungi in forest reclamation after surface mining and agricultural disturbances: a review. Dendrobiology. 2016;76:91-104. https://doi.org/10.12657/denbio.076 009.

49. Durall DM, Gamiet S, Simard SW, Kudrna L, Sakakibara SM. Effects of clearcut logging and tree species composition on the diversity and community 
composition of epigeous fruit bodies formed by ectomycorrhizal fungi. Botany. 2006;84(6):966-80. https://doi.org/10.1139/B06-045.

50. Stankeviciene D, Kasparavicius J. Studies on ectomycorrhizal basidiomycete in pine forest on the Lithuania-Poland transboundary region. Acta Mycol. 2007;42(1):68. https://doi.org/10.5586/am.2007.004.

51. Martínez-Peña F, Ágreda T, Áqueda B, Ortega-Martínez P, Fernández-Toirán LM. Edible sporocarp production by age class in a Scots pine stand in Northern Spain. Mycorrhiza. 2012;22(3):167-74. https://doi.org/10.1007/ s00572-011-0389-8.

52. Eilertsen L. Presence of Hydnellum species on pine heaths. Umeå: Umeå University; 2014

53. Łuczaj $Ł$, Sadowska B. Edge effect in different groups of organisms: vascular plant, bryophyte and fungi species richness across a forest-grassland border. Folia Geobotan Phytotaxonom. 1997;32(4):343-53. https://doi.org/10.1007/ bf02821940

54. Lavoie M, Paré D, Bergeron Y. Relationships between microsite type and the growth and nutrition of young black spruce on post-disturbed lowland black spruce sites in eastern Canada. Can J Forest Res. 2006;37(1):62-73. https://doi.org/10.1139/X06-196.

55. Boddy L. Interspecific combative interactions between wood-decaying basidiomycetes. FEMS Microbiol Ecol. 2000;31(3):185-94. https://doi.org/10.1 016/50168-6496(99)00093-8.

56. Bonet JA, De-Miguel S, de Aragón JM, Pukkala T, Palahí M. Immediate effect of thinning on the yield of Lactarius group deliciosus in Pinuspinaster forests in Northeastern Spain. Forest Ecol Manage. 2012;265:211-7. https:// doi.org/10.1016/j.foreco.2011.10.039

57. Kucuker MD, Baskent EZ. Modeling the productivity of commercial Lactarius mushrooms: a case study in the Kizilcasu planning unit, Turkey. Nat Res Model. 2019;32(1):e12178. https://doi.org/10.1111/nrm.12178.

58. Zhu JJ, Li FQ, Xu ML, Kang HZ, Wu XY. The role of ectomycorrhizal fungi in alleviating pine decline in semiarid sandy soil of northern China: an experimental approach. Ann Forest Sci. 2008;65(3):1. https://doi.org/10.1051/ forest:2008007.

59. Johnson LM, Hunn ES. Landscape ethnoecology: concepts of biotic and physical space. New York: Berghahn Books; 2010. https://doi.org/10.1080/ 00207233.2012 .688466

60. Hobson G. Traditional knowledge is science. Northern Perspect. 1992;20(1):2.

61. Hintikka V. On the macromycete flora in oligotrophic pine forests of different ages in South Finland. Acta Bot Fenn. 1988;136:89-94.

62. Koide RT, Malcolm GM. N concentration controls decomposition rates of different strains of ectomycorrhizal fungi. Fungal Ecol. 2009;2(4):197-202. https://doi.org/10.1016/j.funeco.2009.06.001.

63. Aučina A, Rudawska M, Leski T, Skridaila A, Riepšas E, Iwanski M. Growth and mycorrhizal community structure of Pinus sylvestris seedlings following the addition of forest litter. Appl. Environ. Microbiol. 2007;73(15):4867-73. https://doi.org/10.1128/AEM.00584-07.

64. Bödeker IT, Clemmensen KE, de Boer W, Martin F, Olson Å, Lindahl BD, Ectomycorrhizal Cortinarius species participate in enzymatic oxidation of humus in northern forest ecosystems. New Phytologist. 2014;203(1):245-56. https://doi.org/10.1111/nph.12791.

65. Reid, D. A. Changes in the British macromycete flora. In The Changing Flora and Fauna of Britain (cd. D. L. Hawksworth), pp. 1974;79-85. Londyn, Nowy Jork.

66. Pinna S, Gévry MF, Côté M, Sirois L. Factors influencing fructification phenology of edible mushrooms in a boreal mixed forest of Eastern Canada. Forest Ecol Manage. 2010;260(3):294-301. https://doi.org/10.1016/j. foreco.2010.04.024

67. Liu B, Bonet JA, Fischer CR, de Aragón JM, Bassie L, Colinas C. Lactarius deliciosus Fr. soil extraradical mycelium correlates with stand fruitbody productivity and is increased by forest thinning. Forest Ecol Manage. 2016; 380:196-201. https://doi.org/10.1016/j.foreco.2016.08.053.

68. Castaño C, Alday JG, Parladé J, Pera J, de Aragón JM, Bonet JA. Seasonal dynamics of the ectomycorrhizal fungus Lactarius vinosus are altered by changes in soil moisture and temperature. Soil Biol Biochem. 2017;115:25360. https://doi.org/10.1016/j.soilbio.2017.08.021.

69. Sotek Z, Stasińska M. Różnorodność macromycetes na tle przemian roślinności na torfowisku atlantyckim" Stramniczka". Woda-ŚrodowiskoObszary Wiejskie. 2010;10:257-70.

70. Carleton TJ, Read DJ. Ectomycorrhizas and nutrient transfer in coniferfeather moss ecosystems. Can J Bot. 1991;69(4):778-85. https://doi.org/1 0.1139/b91-101.
71. Pilz, D., Norvell, L., Danell, E., \& Molina, R. Ecology and management of commercially harvested chanterelle mushrooms. Gen. Tech. Rep. PNW-GTR576. Portland, OR: US Department of Agriculture, Forest Service, Pacific Northwest Research Station. 2003;83 p, 576. DOI: https://doi.org/10.2737/ PNW-GTR-576

72. Kauserud $\mathrm{H}$, Mathiesen $\mathrm{C}$, Ohlson M. High diversity of fungi associated with living parts of boreal forest bryophytes. Botany. 2008;86(11):1326-33. https:// doi.org/10.1139/B08-102.

73. Rochon C, Paré D, Pélardy N, Khasa DP, Fortin JA. Ecology and productivity of Cantharellus cibarius var. roseocanus in two eastern Canadian jack pine stands. Botany. 2001;89(10):663-75. https://doi.org/10.1139/b11-058.

74. Veijalainen $\mathrm{H}$. Effect of forestry on the yields of wild berries and edible fungi. Ecol Bull. 1976:63-5.

75. Jalkanen R, Jalkanen E. Studies on the effects of soil surface treatments on crop of false morel (Gyromitra esculenta) in spruce forests. Karstenia. 1978; $18(18$ (suppl.)):56-7. https://doi.org/10.29203/ka.1978.159.

76. Omura K. Science against modern science: the socio-political construction of otherness in Inuit TEK (traditional ecological knowledge). Senri Ethnol Stud. 2005;67, 323-344.

77. Ohenoja E. Effect of forest management procedures on fungal fruit body production in Finland. Acta Bot Fenn. 1988;136:81-4.

78. Goldway M, Rachel AMIR, Goldberg D, Hadar Y, Levanon D. Morchella conica exhibiting a long fruiting season. Mycological Research. 2000;104(8): 1000-4. https://doi.org/10.1017/\$0953756200002598.

79. Egli S, Ayer F, Peter M, Eilmann B, Rigling A. Is forest mushroom productivity driven by tree growth? Results from a thinning experiment. Ann Forest Sci. 2010;67(5):509. https://doi.org/10.1051/forest/2010011.

80. Tomao A, Bonet JA, de Aragón JM, de Miguel S. Is silviculture able to enhance wild forest mushroom resources? Current knowledge and future perspectives. Forest Ecol Manage. 2017;402:102-14. https://doi.org/10.1016/j. foreco.2017.07.039.

81. Dickie IA, Reich PB. Ectomycorrhizal fungal communities at forest edges. J Ecol. 2005;93(2):244-55. https://doi.org/10.1111/j.1365-2745.2005.00977.x.

82. Dickie IA, Dentinger BTM, Avis PG, McLaughlin DJ, Reich PB. Ectomycorrhizal fungal communities of oak savanna are distinct from forest communities. Mycologia. 2009;101(4):473-83. https://doi.org/10.3852/08-178.

83. Żółciak, A. Inokulacja pniaków liściastych grzybnią boczniaka ostrygowatego [Pleurotus ostreatus] jako biologiczna metoda zabezpieczania przed opieńkową zgnilizną korzeni. Prace Instytutu Badawczego Leśnictwa. 2002; Seria A, (4 [944-947]), 5-19.

84. Schlumpf E. Sollen unsere Pilze aussterben. Schweizerische Zeitschrift Pilzkunde. Benteli Verlag. 1976;54:101-5.

85. Jansen $\mathrm{E}$, de Wit T. Veranderingen in de verspreiding van de Cantharel in Nederland. Coolia. 1978;21:117-23.

86. Jaenike J. Mass Extinction of European Fungi. Tree. 1991;6(6):174-5.

87. Cherfas J. Disappearing mushrooms: another mass extinction? Science. 1991;254(5037):1458-9. https://doi.org/10.1139/b91-101.

88. Arnolds E. The changing macromycete flora in the Netherlands. Transact $\mathrm{Br}$ Mycol Soc. 1988;90(3):391-406. https://doi.org/10.1016/S0007-1536(88)80148-7.

89. Arnolds E. Decline of ectomycorrhizal fungi in Europe. Agri Ecosyst Environ. 1991;35(2-3):209-44. https://doi.org/10.1016/0167-8809(91)90052-Y.

90. Arnolds E. Conservation and management of natural populations of edible fungi. Can J Bot. 1995;73(S1):987-98. https://doi.org/10.1139/b95-349.

91. Molnár Z. Classification of pasture habitats by Hungarian herders in a steppe landscape (Hungary). J Ethnobiol Ethnomed. 2012;8(1):28. https://doi. org/10.1186/1746-4269-8-28.

92. Kundzewicz, Z. W., \& Matczak, P. Climate change regional review. Wiley Interdisciplinary Reviews: Climate Change, 2012;3(4), 297-311. doi: https:// doi.org/10.1002/wcc.175

93. Somorowska U. Soil water storage in Poland over the years 2000-2015 in response to precipitation variability as retrieved from GLDAS Noah simulations. Geographia Polonica. 2017;90(1):53-64. https://doi.org/10.7163/ GPol.0078.

94. Wiklund K, Nilsson LO, Jacobsson S. Effect of irrigation, fertilization, and artificial drought on basidioma production in a Norway spruce stand. Can J Bot. 1995;73(2):200-8. https://doi.org/10.1139/b95-023.

95. Ogaya R, Peñuelas J. Decreased mushroom production in a holm oak forest in response to an experimental drought. Forestry. 2005;78(3):279-83. https:/ doi.org/10.1093/forestry/cpi025.

96. De Aragón JM, Bonet JA, Fischer CR, Colinas C. Productivity of ectomycorrhizal and selected edible saprotrophic fungi in pine forests of 
the pre-Pyrenees mountains, Spain: predictive equations for forest management of mycological resources. Forest Ecol Manage. 2007;252(1-3): 239-56. https://doi.org/10.1016/j.foreco.2007.06.040.

97. Wilkins WH, Harris GCM. The ecology of the larger fungi V. An investigation into the influence of rainfall and temperature on seasonal production of fungi in a beechwood and a pinewood. Ann Appl Biol. 1946;33(2):179-88. https://doi.org/10.1111/j.1744-7348.1946.tb06295.x.

98. Dahlberg A. Ectomycorrhiza in coniferous forest: structure and dynamics of populations and communities. Uppsala: Ph.D. thesis, Department of Forest Mycology and Pathology, Swedish University of Agricultural Sciences; 1991.

99. Gange AC, Gange EG, Sparks TH, Boddy L. Rapid and recent changes in fungal fruiting patterns. Science. 2007;316(5821):71. https://doi.org/10.1126/ science.1137489.

100. Schär C, Vidale PL, Lüthi D, Frei C, Häberli C, Liniger MA, et al. The role of increasing temperature variability in European summer heatwaves. Nature. 2004;427(6972):332-6. https://doi.org/10.1038/nature02300.

101. Kręgiel B, Jarosińska E. Obecny stan monitoringu zjawiska suszy w Polsce i na świecie. Czasopismo Techn Środowisko. 2009;106(3-Ś):87-99.

102. Egli S, Peter M, Buser C, Stahel W, Ayer F. Mushroom picking does not impair future harvests-results of a long-term study in Switzerland. Biol Conserv. 2006;129(2):271-6. https://doi.org/10.1016/j.biocon.2005.10.042.

103. Frey B, Kremer J, Rüdt A, Sciacca S, Matthies D, Lüscher P. Compaction of forest soils with heavy logging machinery affects soil bacterial community structure. Eur J Soil Biol. 2009;45(4):312-20. https://doi.org/10.1016/j.ejsobi.2 009.05.006.

104. Vitousek PM. Beyond global warming: ecology and global change. Ecology. 1994;75(7):1861-76. https://doi.org/10.2307/1941591.

105. Kottke I, Qian XM, Pritsch K, Haug I, Oberwinkler F. Xerocomus badius-Picea abies, an ectomycorrhiza of high activity and element storage capacity in acidic soil. Mycorrhiza. 1998;7(5):267-75. https://doi.org/10.1007/s00572 0050191.

106. Rosinger C, Sandén H, Matthews B, Mayer M, Godbold D. Patterns in ectomycorrhizal diversity, community composition, and exploration types in European beech, pine, and spruce forests. Forests. 2018;9(8):445. https://doi. org/10.3390/f9080445.

107. Clemmensen KE, Michelsen A, Jonasson S, Shaver GR. Increased ectomycorrhizal fungal abundance after long-term fertilization and warming of two arctic tundra ecosystems. New Phytologist. 2006;171(2):391-404. https://doi.org/10.1111/j.1469-8137.2006.01778.x.

108. Morgado LN, Semenova TA, Welker JM, Walker MD, Smets E, Geml J. Summer temperature increase has distinct effects on the ectomycorrhizal fungal communities of moist tussock and dry tundra in Arctic Alaska. Global Change Biol. 2015;21 (2):959-72. https://doi.org/10.1111/gcb.12716.

109. Fernandez CW, Nguyen NH, Stefanski A, Han Y, Hobbie SE, Montgomery RA, et al. Ectomycorrhizal fungal response to warming is linked to poor host performance at the boreal-temperate ecotone. Global Change Biol. 2017; 23(4):1598-609. https://doi.org/10.1111/gcb.13510.

110. Lamhamedi MS, Bernier PY, André-Fortin J. Hydraulic conductance and soil water potential at the soil-root interface of Pinus pinaster seedlings inoculated with different dikaryons of Pisolithus sp. Tree Physiol. 1992;10(3): 231-44. https://doi.org/10.1093/treephys/10.3.231.

111. Risbeth J. The production of rhizomorphs by Armillaria mellea from stumps. Eur. J. For. Path. 1972;2(4):193-205. https://doi.org/10.1111/j.1439-0329.1972. tb00363.x.

112. Szwed M, Karg G, Pińskwar I, Radziejewski M, Graczyk D, Kędziora A, et al. Climate change and its effect on agriculture, water resources and human health sectors in Poland. Nat Hazards Earth Syst Sci. 2010;10(8):1725-37. https://doi.org/10.5194/nhess-10-1725-2010.

113. International Society of Ethnobiology Code of Ethics (with 2008 additions). 2013; Available from: http://ethnobiology.net/code-of-ethics [Accessed on 2018 Aug 17]

114. American Anthropological Association Code of Ethics. 2009; Available from: http://s3.amazonaws.com/rdcms-aaa/files/production/public/FileDownloads/ pdfs/issues/policy-advocacy/upload/AAA-Ethics-Code2009.pdf [Accessed on 2018 Aug 17]

\section{Publisher's Note}

Springer Nature remains neutral with regard to jurisdictional claims in published maps and institutional affiliations.

Ready to submit your research? Choose BMC and benefit from:

- fast, convenient online submission

- thorough peer review by experienced researchers in your field

- rapid publication on acceptance

- support for research data, including large and complex data types

- gold Open Access which fosters wider collaboration and increased citations

- maximum visibility for your research: over $100 \mathrm{M}$ website views per year

At BMC, research is always in progress.

Learn more biomedcentral.com/submissions 